\title{
ECONOMIC IMPLICATIONS OF THE REGIONAL COMPREHENSIVE ECONOMIC PARTNERSHIP FOR ASIA AND THE PACIFIC
}

Cyn-Young Park, Peter A. Petri, and Michael G. Plummer

NO. 639

October 2021
ADB ECONOMICS WORKING PAPER SERIES 


\section{ADB Economics Working Paper Series}

\section{Economic Implications of the Regional Comprehensive Economic Partnership for Asia and the Pacific}

Cyn-Young Park, Peter A. Petri, and Michael G. Plummer

No. 639 | October 2021
Cyn-Young Park (cypark@adb.org) is a director at the Economic Research and Regional Cooperation Department (ERCD), Asian Development Bank (ADB). Peter A. Petri (ppetri@brandeis.edu) is a professor at Brandeis International Business School, and a non-resident senior fellow at the Brookings Institution. Michael G. Plummer (mplummer@jhu.edu) is the director of the School of Advanced International Studies (SAIS) Europe, Johns Hopkins University; and a non-resident senior fellow at the East-West Center.

In addition to participants at the ADB-ERCD Research Seminar on 3 June 2021, the authors thank Sang-Hyop Lee (University of Hawaii), Andrew Mason (East-West Center), Marinos Tsigas (United States International Trade Commission), Anna Robeniol (Association of Southeast Asian Nations Secretariat), Carmen Estrades (Universidad de la República, Uruguay), and Pramila Crivelli (ADB) for offering insightful comments and sharing their valuable data; and Mara Tayag for data support. 
(C) 2021 Asian Development Bank

6 ADB Avenue, Mandaluyong City, 1550 Metro Manila, Philippines

Tel +632 8632 4444; Fax +63286362444

www.adb.org

Some rights reserved. Published in 2021.

ISSN 2313-6537 (print), 2313-6545 (electronic)

Publication Stock No. WPS210371-2

DOI: http://dx.doi.org/10.22617/WPS210371-2

The views expressed in this publication are those of the authors and do not necessarily reflect the views and policies of the Asian Development Bank (ADB) or its Board of Governors or the governments they represent.

ADB does not guarantee the accuracy of the data included in this publication and accepts no responsibility for any consequence of their use. The mention of specific companies or products of manufacturers does not imply that they are endorsed or recommended by ADB in preference to others of a similar nature that are not mentioned.

By making any designation of or reference to a particular territory or geographic area, or by using the term "country" in this document, $A D B$ does not intend to make any judgments as to the legal or other status of any territory or area.

This work is available under the Creative Commons Attribution 3.0 IGO license (CC BY 3.0 IGO)

https://creativecommons.org/licenses/by/3.0/igo/. By using the content of this publication, you agree to be bound by the terms of this license. For attribution, translations, adaptations, and permissions, please read the provisions and terms of use at https://www.adb.org/terms-use\#openaccess.

This CC license does not apply to non-ADB copyright materials in this publication. If the material is attributed to another source, please contact the copyright owner or publisher of that source for permission to reproduce it. $\mathrm{ADB}$ cannot be held liable for any claims that arise as a result of your use of the material.

Please contact pubsmarketing@adb.org if you have questions or comments with respect to content, or if you wish to obtain copyright permission for your intended use that does not fall within these terms, or for permission to use the ADB logo.

Corrigenda to ADB publications may be found at http://www.adb.org/publications/corrigenda.

Notes:

In this publication, “\$” refers to United States dollars.

ADB recognizes "China" as the People's Republic of China.

The ADB Economics Working Paper Series presents data, information, and/or findings from ongoing research and studies to encourage exchange of ideas and to elicit comment and feedback about development issues in Asia and the Pacific. Since papers in this series are intended for quick and easy dissemination, the content may or may not be fully edited and may later be modified for final publication. 


\section{CONTENTS}

TABLES AND FIGURES

ABSTRACT V v v v v v v v v

$\begin{array}{ll}\text { I. INTRODUCTION } & 1\end{array}$

II. THE REGIONAL COMPREHENSIVE ECONOMIC PARTNERSHIP AGREEMENT 2

III. MODELING THE EFFECTS OF THE REGIONAL COMPREHENSIVE 6 ECONOMIC PARTNERSHIP AGREEMENT

IV. ESTIMATES OF THE EFFECTS OF THE REGIONAL COMPREHENSIVE ECONOMIC PARTNERSHIP AGREEMENTAND OTHER POLICIES
A. $\quad$ Aggregate Income and Trade Effects of Major Policy Changes 9
B. $\quad$ Labor Market Implications of Trade Policy Developments 12
C. Sources of Income and Trade Gains 14
D. How Policy Changes Will Affect Trade Patterns 17
E. Sectoral Effects of Trade Policies 19

$\begin{array}{ll}\text { V. CONCLUSION } & 21\end{array}$

$\begin{array}{ll}\text { APPENDIX } & 23\end{array}$

$\begin{array}{lr}\text { REFERENCES } & 26\end{array}$ 


\section{TABLES AND FIGURES}

\section{TABLES}

$1 \quad$ Provisions of the Comprehensive and Progressive Agreement on Trans-Pacific

Partnership and the Regional Comprehensive Economic Partnership Agreement

2 Specifications for Simulating Asia and the Pacific Policies 7

3 Income Effects of Asia and the Pacific Policies 9

4 Export Effects of Asia and the Pacific Policies 10

5 Barriers Applied to the Regional Comprehensive Economic Partnership 15 Exports in Intra-RCEP Trade, by Exporter

6 Barriers Applied to the Regional Comprehensive Economic Partnership 19 Exports in Intra-RCEP Trade, by Sector

A1 Labor Supply Elasticities $\epsilon$

\section{FIGURES}

$1 \quad$ Real Returns to Labor under Asia and the Pacific Policies

2 Employment Effects under Asia and the Pacific Policies

3 Composition of Global Income Effects of the Regional Comprehensive Economic Partnership, by Liberalization Instrument

4 Composition of the Global Trade Effects of the Regional Comprehensive Economic Partnership, by Liberalization Instrument

5 Export Changes under Asia and the Pacific Policies 


\begin{abstract}
The Regional Comprehensive Economic Partnership (RCEP) presents strong potential to mold regional trade and investment patterns well into the future and to influence the direction of global economic cooperation at a challenging time. This paper evaluates the RCEP and estimates its potential effects on income, trade, economic structure, factor returns, and employment using a computable general equilibrium model. The results suggest that the RCEP agreement could generate global income gains that will be almost twice as large as those of the Comprehensive and Progressive Agreement on Trans-Pacific Partnership (CPTPP). RCEP effects on the region's trade will also significantly deepen regional production networks and raise productivity. At the sectoral level, exports and imports of nondurable and durable manufactures will experience the most growth. The CPTPP and RCEP will especially strengthen the region's manufacturing supply chains, increasing wages and employment.
\end{abstract}

Keywords: computable general equilibrium, Comprehensive and Progressive Agreement on Trans-Pacific Partnership, free trade agreement, Regional Comprehensive Economic Partnership, rules of origin, supply chains

JEL codes: F13, F15, F17 


\section{INTRODUCTION}

The 15 negotiating parties of the Regional Comprehensive Economic Partnership (RCEP) made history on 15 November 2020 by signing the largest free-trade agreement (FTA) ever in size ( $\$ 26$ trillion in gross domestic product) and population (2.3 billion). It is the second "megaregional" trade agreement in Asia and the Pacific, following the Comprehensive and Progressive Agreement on Trans-Pacific Partnership (CPTPP) that became effective in December 2018. The two agreements have the potential to mold regional trade and investment patterns well into the future and to influence the direction of global economic cooperation at a challenging time.

This paper evaluates the RCEP and estimates its potential effects on income, trade, economic structure, factor returns, and employment. It uses a computable general equilibrium (CGE) model based on information from the newly released RCEP text. The results identify especially important areas to participating countries and provide priorities for updating and exploring the detailed implications of the agreement, particularly as it expands in scope and membership.

The path to the RCEP was long and difficult. After two decades of preliminary discussions, negotiations were launched in November 2012 for an ASEAN-centric agreement that would include the 10 members of the Association of Southeast Asian Nations (ASEAN) and six "dialogue partners": the Northeast Asian economies of the People's Republic of China (PRC), Japan, and the Republic of Korea; the Oceanic countries of Australia and New Zealand; and the South Asian country of India. The negotiations spanned some of the world's richest and most developed economies with some of its poorest and least developed, constraining the ambition of the agreement. But diversity was also the RCEP's biggest draw: it enables a more efficient division of labor and enhances the potential for deepening existing supply chains and creating many new ones.

If the RCEP delivers on its promise, it will become a model for managing the diverging interests and sensitivities of developing and developed economies in an ambitious agreement, with obvious implications for wider multilateral cooperation. It took 30 rounds of negotiations and four summits to conclude the agreement, but even so, India withdrew from the process in its final stages in November 2019. The loss of India was a blow, but the agreement underscores that India would be welcomed back at any time.'

Understanding the value added of the RCEP is complicated by the region's multiple existing FTAs. For example, ASEAN economies already have FTAs with each other, as well as an ambitious economic integration program known as the ASEAN Economic Community, which went into effect in December 2015 and continues to deepen. One would not expect, a priori, the RCEP to significantly lower intra-ASEAN barriers to trade and investment. The same would be true of barriers between Australia and New Zealand, whose Closer Economic Relations agreement is one of the most advanced FTAs in the world. Further, all RCEP members have an FTA in place with ASEAN (a condition to join negotiations), called "ASEAN+1" agreements, with different scope and ambitions, and many have FTAs with each other. While the PRC and the Republic of Korea also have a limited FTA, there was no regional FTA binding the PRC, Japan, and the Republic of Korea together. The RCEP will change that.

Chapter 20 of RCEP agreement notes that all other applicants must wait at least 18 months after entry into force of the agreement (Table 1). 
At the same time, a comprehensive template added to many existing FTAs, along with common rules to bind the "noodle bowl" of bilateral agreements together, themselves suggest significant benefits from the RCEP. Cumulative, common rules of origin bolster integration and enhance the impact of tariff reductions. Well implemented, consolidated rules, streamlined regulatory procedures, and expanded market access could have great impact on reducing nontariff barriers in this large region, with commensurate benefits for trade, investment, and economic growth.

This paper will show that the RCEP is likely to make significant contributions to the region and the global economy. By 2030, if implementation is on track, we estimate that it will increase members' incomes by $0.6 \%$, adding $\$ 245$ billion annually to regional income and 2.8 million jobs to regional employment. These benefits will be more than twice those projected for the CPTPP agreement. Every RCEP member will gain, but as expected, the largest percentage increases will be realized by the region's most trade-oriented economies, such as Malaysia and Viet Nam; the Northeast Asian economies with no prior trade agreements with each other, such as Japan and the Republic of Korea; and countries throughout the region that can effectively participate in regional supply chains, including Cambodia, the Lao People's Democratic Republic, the PRC, and Thailand.

The results suggest especially strong gains in trade and production links-and thus in productivity. Increases in trade will be approximately 2-3 times as large as increases in income, reflecting substantial trade in intermediate goods. New trade will mostly affect manufacturing industries and their supply chains, but gains are also projected for primary goods and service flows.

Finally, the results underline the importance of effective implementation. Liberalization of nontariff barriers in goods and services will be the most important driver of projected benefits, accounting for approximately two-thirds of the total effects of the RCEP on income. This will require coordinated changes in domestic policies, partly managed by the agreement's built-in consultation mechanisms. The full and transparent implementation of scheduled tariff cuts and rules-of-origin reforms will be also essential.

The paper is organized as follows. Section II reviews the contents of the RCEP agreement. Section III reviews the modeling approach, and Section IV summarizes estimates of the impact of the RCEP and other policy developments on income, trade, economic structure, factor returns, and employment. Section $V$ concludes. The Appendix provides further detail on our CGE model.

\section{THE REGIONAL COMPREHENSIVE ECONOMIC PARTNERSHIP AGREEMENT}

The RCEP is one of several major regional agreements that have taken over the work of modernizing the global trading system given the stalemate in the World Trade Organization (WTO) (Pomfret 2021). It includes 20 chapters covering most aspects of contemporary trade relations, many of which follow the chapters of the CPTPP, an even more ambitious agreement. ${ }^{2}$ In discussing the key features of the RCEP, we therefore use the CPTPP as a benchmark and include it in our policy simulations. ${ }^{3}$

2 For a copy of all chapters of the agreement see https://dfat.gov.au/trade/agreements/negotiations/rcep/Pages/regionalcomprehensive-economic-partnership.aspx

3 For economic estimates of CPTPP expansion scenarios, including the potential accession of the PRC and five other East Asian economies which have expressed interest in joining, see Petri and Plummer (2019). 
While the RCEP is not as wide-ranging as the CPTPP_-for example, it does not include provisions on labor and environmental standards or state-owned enterprises-it is reasonably comprehensive, covering trade in goods and services; cumulative and trade-friendly rules of origin; customs procedures and trade facilitation; sanitary and phytosanitary measures; standards, technical regulations, and conformity assessment procedures; and trade remedies. The memberships of the agreements overlap: 7 of 11 CPTPP members also signed the RCEP.

Table 1 compares the main features of the RCEP and the CPTPP, recognizing that a careful mapping of the legal text would require longer and more technical analysis. The RCEP is long-at over 6,000 pages-because it includes detailed schedules that record how individual members exercised the flexibilities offered by the agreement. In part, these flexibilities address the needs of the region's least developed countries, Cambodia and the Lao People's Democratic Republic. But they are not limited to these countries-positive lists are used for services liberalization in five other RCEP economies, including the PRC and New Zealand.

\section{Table 1: Provisions of the Comprehensive and Progressive Agreement on Trans-Pacific Partnership and the Regional Comprehensive Economic Partnership Agreement}

\begin{tabular}{|c|c|c|c|c|}
\hline Major Issues & $\begin{array}{l}\text { CPTPP } \\
\text { Chapter }\end{array}$ & RCEP Chapter & CPTPP Content & Expected RCEP Differences \\
\hline $\begin{array}{l}\text { National treatment } \\
\text { and market access } \\
\text { for trade in goods }\end{array}$ & 2 & 2 & $\begin{array}{l}\text { Application of national and } \\
\text { most favored nation treatment, } \\
\text { transparent tariffs. }\end{array}$ & Same. \\
\hline Rules of origin & 3,4 & $\begin{array}{l}3 \text { (Annexes } 3 a \text { on } \\
\text { product specific } \\
\text { rules, and } 3 b \text { on info } \\
\text { requirements) }\end{array}$ & $\begin{array}{l}\text { Favorable definitions and } \\
\text { costing methods for } \\
\text { cumulation. De minimis } \\
\text { treatment of non-originating } \\
\text { materials. Special provisions for } \\
\text { textiles and apparel. }\end{array}$ & $\begin{array}{l}\text { Regional value-added } \\
\text { requirement generally a } \\
\text { liberal } 40 \% \text {. }\end{array}$ \\
\hline $\begin{array}{l}\text { Customs } \\
\text { administration and } \\
\text { trade facilitation }\end{array}$ & 5 & $\begin{array}{l}4 \text { (Annex } 4 a \text { on } \\
\text { timing of } \\
\text { implementation) }\end{array}$ & $\begin{array}{l}\text { Enhanced customs } \\
\text { cooperation, trade facilitation, } \\
\text { express shipments, } \\
\text { administration of customs } \\
\text { penalties. }\end{array}$ & $\begin{array}{l}\text { Same goals and focus on } \\
\text { consistency, transparency, } \\
\text { efficiency. }\end{array}$ \\
\hline Trade remedies & 6 & $\begin{array}{l}7 \text { (Annex } 7 \mathrm{a} \text { on } \\
\text { antidumping and } \\
\text { countervailing } \\
\text { duties) }\end{array}$ & $\begin{array}{l}\text { Rules for safeguards, temporary } \\
\text { protection, antidumping and } \\
\text { countervailing duties. }\end{array}$ & Same coverage. \\
\hline $\begin{array}{l}\text { Sanitary and } \\
\text { phytosanitary } \\
\text { measures }\end{array}$ & 7 & 5 & $\begin{array}{l}\text { Rules for sanitary and } \\
\text { phytosanitary measures, } \\
\text { equivalence recognition, } \\
\text { science and risk analysis, audits, } \\
\text { certification, and transparency. }\end{array}$ & $\begin{array}{l}\text { Same in general, World Trade } \\
\text { Organization (WTO+), also } \\
\text { includes capacity building. }\end{array}$ \\
\hline $\begin{array}{l}\text { Technical barriers } \\
\text { to trade }\end{array}$ & 8 & 6 & $\begin{array}{l}\text { Enhanced cooperation on } \\
\text { standards for technical } \\
\text { regulations, conformity } \\
\text { assessment. }\end{array}$ & $\begin{array}{l}\text { Standards, technical regulations, } \\
\text { and conformity assessment } \\
\text { procedures. }\end{array}$ \\
\hline
\end{tabular}


Table 1 continued

\begin{tabular}{|c|c|c|c|c|}
\hline Major Issues & $\begin{array}{l}\text { CPTPP } \\
\text { Chapter }\end{array}$ & RCEP Chapter & CPTPP Content & Expected RCEP Differences \\
\hline Investment & 9 & $\begin{array}{l}10 \text { (Annex } 10 \mathrm{~A} \\
\text { customary } \\
\text { international law; } \\
\text { Annex } 10 \mathrm{~B} \\
\text { expropriation) }\end{array}$ & $\begin{array}{l}\text { National treatment, most } \\
\text { favored nation treatment, } \\
\text { compensation for } \\
\text { expropriation, rules for financial } \\
\text { transfers, bar performance } \\
\text { requirements, investor-state } \\
\text { dispute settlement with } \\
\text { improved safeguards for public } \\
\text { welfare regulations. Phasing out } \\
\text { equity limits in some countries. }\end{array}$ & $\begin{array}{l}\text { Similar structure but permits } \\
\text { positive lists for exceptions. } \\
\text { Investor-state dispute } \\
\text { settlement not yet included but } \\
\text { part of work program, with } \\
\text { discussions to begin two years } \\
\text { after entry into force. }\end{array}$ \\
\hline $\begin{array}{l}\text { Cross-border trade } \\
\text { in services }\end{array}$ & $10,11,13$ & $\begin{array}{l}8 \text { (Annex A financial } \\
\text { services; Annex B } \\
\text { telecommunications } \\
\text { services; Annex } C \\
\text { Professional } \\
\text { services) }\end{array}$ & $\begin{array}{l}\text { Disciplines on market restrictions, } \\
\text { local presence requirements, } \\
\text { regulations, criteria for service } \\
\text { providers. Special provisions for } \\
\text { financial services for offering new } \\
\text { products and restricting } \\
\text { regulations, for educational } \\
\text { services in enhancing offerings, } \\
\text { and for telecommunications } \\
\text { services on interconnection, } \\
\text { roaming. }\end{array}$ & $\begin{array}{l}\text { Includes negative lists for seven } \\
\text { countries and positive lists for } \\
\text { eight; national treatment; special } \\
\text { and differential treatment for } \\
\text { least developed countries; lists } \\
\text { offered by members are } \\
\text { extensive (over } 1,000 \text { pages, } \\
\text { Baker McKenzie } 2020 \text { ). All } \\
\text { should transition to negative-list } \\
\text { approach within } 6 \text { years of entry } \\
\text { into force. }\end{array}$ \\
\hline $\begin{array}{l}\text { Temporary entry } \\
\text { for business } \\
\text { persons }\end{array}$ & 12 & 9 & $\begin{array}{l}\text { Disciplines on regulating } \\
\text { temporary entry of business } \\
\text { persons. Country-specific } \\
\text { concessions for additional } \\
\text { professional services and longer } \\
\text { periods of stay. }\end{array}$ & $\begin{array}{l}\text { Takes essentially same } \\
\text { approach, focus on } \\
\text { transparency, cooperation to } \\
\text { further facilitate movement. }\end{array}$ \\
\hline $\begin{array}{l}\text { Electronic } \\
\text { commerce }\end{array}$ & 14 & 12 & $\begin{array}{l}\text { Prohibits customs duties on } \\
\text { electronic transmissions, } \\
\text { discriminatory treatment of } \\
\text { digital products. Sets legal } \\
\text { framework for e-commerce. } \\
\text { Limits restrictions on } \\
\text { cross-border transmission } \\
\text { of data and location of } \\
\text { computing facilities. }\end{array}$ & $\begin{array}{l}\text { Trade facilitation, no customs } \\
\text { duties on electronic transfers; } \\
\text { no impediments to cross-border } \\
\text { data flows and no data } \\
\text { localization requirements, } \\
\text { except to promote public } \\
\text { objectives, national security. }\end{array}$ \\
\hline $\begin{array}{l}\text { Government } \\
\text { procurement }\end{array}$ & 15 & 16 & $\begin{array}{l}\text { National treatment and } \\
\text { nondiscrimination, governance } \\
\text { of procurement, expanded } \\
\text { range of organizations covered. }\end{array}$ & $\begin{array}{l}\text { Focuses on transparency and } \\
\text { cooperation, no obligations for } \\
\text { least developed countries, no } \\
\text { application of dispute } \\
\text { settlement. }\end{array}$ \\
\hline $\begin{array}{l}\text { Competition and } \\
\text { regulatory policy }\end{array}$ & $16,25,26$ & $\begin{array}{l}13 \text { (Annexes on } \\
\text { measures against } \\
\text { anticompetitive } \\
\text { activities by country } \\
\text { groups) }\end{array}$ & $\begin{array}{l}\text { Ensures fairness in competition } \\
\text { law, enables private right of } \\
\text { action. Enhanced regulatory } \\
\text { coherence, transparency, } \\
\text { anticorruption measures. }\end{array}$ & $\begin{array}{l}\text { Measures against } \\
\text { anticompetitive behavior; } \\
\text { technical cooperation and } \\
\text { capacity building; consumer } \\
\text { protection. }\end{array}$ \\
\hline $\begin{array}{l}\text { State-owned } \\
\text { enterprises and } \\
\text { designated } \\
\text { monopolies }\end{array}$ & 17 & Not applicable & $\begin{array}{l}\text { Defines state-owned } \\
\text { enterprises and designated } \\
\text { monopolies and limits } \\
\text { noncommercial assistance to } \\
\text { state-owned enterprises. }\end{array}$ & Not covered. \\
\hline
\end{tabular}


Table 1 continued

\begin{tabular}{|c|c|c|c|c|}
\hline Major Issues & $\begin{array}{l}\text { CPTPP } \\
\text { Chapter }\end{array}$ & RCEP Chapter & CPTPP Content & Expected RCEP Differences \\
\hline $\begin{array}{l}\text { Intellectual } \\
\text { property }\end{array}$ & 18 & $\begin{array}{l}11 \text { (11A Party-specific } \\
\text { transition periods; } \\
\text { 11B list of technical } \\
\text { assistance requests) }\end{array}$ & $\begin{array}{l}\text { Commitments to ratify } \\
\text { international agreements on } \\
\text { intellectual property. } \\
\text { US-promoted provisions for } \\
\text { expanded intellectual property } \\
\text { protections under Trans-Pacific } \\
\text { Partnership are suspended. }\end{array}$ & $\begin{array}{l}\text { Same commitments on } \\
\text { international agreements, } \\
\text { improves enforcement, WTO+ } \\
\text { but more limited coverage. }\end{array}$ \\
\hline Labor & 19 & Not applicable. & $\begin{array}{l}\text { Commitments to implement laws } \\
\text { and regulations supporting } \\
\text { International Labour } \\
\text { Organization Declaration } \\
\text { on Labor Rights. Institutions } \\
\text { for review and a Labor Council } \\
\text { for monitoring. }\end{array}$ & Not covered. \\
\hline Environment & 20 & Not applicable & $\begin{array}{l}\text { Recognition of multilateral } \\
\text { environmental agreements. } \\
\text { Provisions on ship pollution, } \\
\text { biodiversity, invasive species, } \\
\text { marine fisheries, conservation. }\end{array}$ & Not covered. \\
\hline $\begin{array}{l}\text { Cooperation and } \\
\text { capacity building }\end{array}$ & $\begin{array}{c}21,22,23 \\
24\end{array}$ & $\begin{array}{l}14 \text { (small and } \\
\text { medium-sized } \\
\text { enterprises), } \\
15 \text { (economic } \\
\text { and technical } \\
\text { cooperation) }\end{array}$ & $\begin{array}{l}\text { Institutions for cooperation and } \\
\text { capacity building, including } \\
\text { especially small and } \\
\text { medium-sized enterprises. }\end{array}$ & $\begin{array}{l}\text { Same general coverage, } \\
\text { resources applied are voluntary, } \\
\text { special considerations for } \\
\text { ASEAN least developed } \\
\text { countries. }\end{array}$ \\
\hline Dispute resolution & 28 & 19 & $\begin{array}{l}\text { Scope of dispute settlement } \\
\text { and a panel for unresolved } \\
\text { disputes. }\end{array}$ & $\begin{array}{l}\text { Process for adjudicating disputes, } \\
\text { creates dispute panel whose } \\
\text { decisions are final and binding, } \\
\text { special and differential treatment } \\
\text { for least developed countries. }\end{array}$ \\
\hline $\begin{array}{l}\text { Definitions, } \\
\text { administration, and } \\
\text { institutions }\end{array}$ & $1,27,29,30$ & $1,17,18,20$ & $\begin{array}{l}\text { Establish the Trans-Pacific } \\
\text { Partnership Commission, } \\
\text { security related exceptions, } \\
\text { safeguard measures, taxation. } \\
\text { Conditions for changes } \\
\text { including enlargement. }\end{array}$ & $\begin{array}{l}\text { Entry into force after ratified by } \\
\text { six ASEAN countries and three } \\
\text { others; enlargement possible } \\
\text { after } 18 \text { months from entry into } \\
\text { force, with exception of India, } \\
\text { which can return at will. }\end{array}$ \\
\hline
\end{tabular}

CPTPP = Comprehensive and Progressive Agreement for Trans-Pacific Partnership, RCEP = Regional Comprehensive Economic Partnership. Source: Authors' compilation.

On the whole, liberalization levels and disciplines included in the RCEP are less rigorous than in the CPTPP. While the CPTPP will eliminate tariffs on $96 \%$ of products that enter intraregional trade, the RCEP is estimated to cover approximately $90 \%$ of goods and, even for these, tariffs will not be fully eliminated in the transition period. Yet its broad coverage bodes well for deepening its provisions in the future, as is typical of ASEAN-centric agreements. For instance, the ASEAN Free Trade Area began in 1992 as an arrangement that only included 10 manufacturing sectors and defined free trade as tariffs between $0 \%-5 \% .{ }^{4}$ Subsequently, it expanded to include all goods, with a relatively small exclusion list,

4 Agreement on the Common Effective Preferential Tariff for the ASEAN Free-Trade Area, Singapore, 28 January 1992. https://asean.org/?static_post=agreement-on-the-common-effective-preferential-tariff-cept-scheme-for-the-aseanfree-trade-area-singapore-28-january-1992 
and reduced tariffs to zero. In the meantime, the region launched the ASEAN Economic Community initiative in 2003 with the ambitious goal of creating a region in which goods, services, skilled labor, and foreign direct investment would flow freely. ${ }^{5}$ The ASEAN Economic Community officially went into effect on 31 December 2015, even though arguably much remains to be done in completing its single market and production base.

In fact, the RCEP has an extensive structure of scheduled meetings and a built-in work plan to facilitate improvements. For example, it does not include an investor-state dispute settlement mechanism but stipulates that discussions begin on setting one up two years after the entry into force of the agreement. The services chapter allows for both positive- and negative-list approaches to increasing market access, but all countries are committed to adopt a negative-list approach within 6 years. Moreover, enlargement applications can be submitted 18 months after entry into force of the agreement, except for India, which can apply at any time.

The RCEP will fall short of the CPTPP in areas of special concern to advanced economies. Its intellectual property provisions add little to those that most members have already accepted in the WTO or other agreements. As noted, the RCEP does not have chapters on labor, the environment, or state-owned enterprises. It does include a chapter on electronic commerce and its provisions stipulate that parties will not apply duties on electronic transmissions, but the treatment of electronic commerce does not appear to go beyond commitments under the WTO (Article 12.11). Impediments to cross-border data transfers and data localization requirements are prohibited, but both are subject to exceptions that could be widely used; parties may apply restrictions in the case of "legitimate public policy objectives" or necessary to the protection of security interests (Article 12.14 and Article 12.15). As noted, provisions on investor-state dispute settlement are not included but will be negotiated no later than 2 years after entry into force of the agreement (Article 10.18).

Nevertheless, the RCEP will be the world's largest regional trade agreement with meaningful coverage and effects. Significantly, it will offer cumulative, favorable rules of origin (ROOs) for manufacturers participating in regional supply chains. It will improve notably on ASEAN+1 agreements by providing consolidated rules that benefit exporters and foreign direct investors. Its market access provisions will set common terms of reference for regulatory policies and extend national and most favored nation treatment to new sectors. Its chapter on customs procedures and trade facilitation will enhance harmonization, regional cooperation, and transparency. And the agreement sets the stage for comprehensive consultations and provides an open enlargement policy.

\section{MODELING THE EFFECTS OF THE REGIONAL COMPREHENSIVE ECONOMIC PARTNERSHIP}

To gauge the expected economic effects of the RCEP, we employ a CGE model. The CGE model remains the workhorse of ex-ante trade policy modeling due to its ability to provide quantitative insight into economy-wide results for multiple regions as well as projections for production and trade in detailed economic sectors. The model used in this paper is described in the Appendix. The model differs from others of its type in some underlying structural assumptions, and in the extensive

5 Declaration of Bali Concord II, 9th ASEAN Summit, 7 October 2003. https://asean.org/?static_post=declaration-ofasean-concord-ii-bali-concord-ii 
sub-model used to represent tariff and nontariff barriers, which include quantitative detail on some 80 relevant regional free trade agreements. The model has 29 regions and 19 economic sectors and dynamically projects annual results from 2015 (the base year) to 2030.

We have used this model in several studies of trade policy over the past decade, initially to assess the implications of the Trans-Pacific Partnership (TPP) and later to examine the CPTPP and RCEP agreements, as well as variants based on different enlargement scenarios. ${ }^{6}$ Unlike these studies, the current paper employs a model specification that includes endogenous labor markets, that is, incorporates positive labor supply responses to real wage changes. This mechanism reflects the relative flexibility of labor markets in RCEP's lower income countries, where rising real wages are likely to attract new workers into the formal labor force. In contrast to previous results, the present simulations therefore include projections of employment changes as well as income changes. This mechanism amplifies the scale of policy effects, since scenarios that yield positive (negative) productivity changes also yield an expansion (contraction) in labor supplies, which in turn reinforce changes in economic activity. ${ }^{7}$ The amplification factor turns out to be as large as $40 \%$, depending on the economy and the simulated policy package.

We build up the analysis of the RCEP agreement from three scenarios that specify changes in the global trade environment. These changes are added to the model's baseline, which is a "business as usual" projection of world economic growth prior to the PRC-US trade conflict. The first scenario represents the intense PRC-US trade war that broke out in 2018 and has persisted since. The second scenario represents the coming into force of the CPTPP agreement in 2018 and its steady implementation in subsequent years. The third scenario defines policy changes from the RCEP itself, which will ramp up gradually over the coming decade. These scenarios enable us to decompose changes in the global trading environment into the incremental effects of the trade war, the CPTPP, and the RCEP.

Table 2: Specifications for Simulating Asia and the Pacific Policies

\begin{tabular}{|c|c|c|c|}
\hline & $\begin{array}{l}\text { PRC-US } \\
\text { Trade War }\end{array}$ & СРТРP & RCEP \\
\hline $\begin{array}{l}\text { Membership, } \\
\text { parties involved }\end{array}$ & PRC, United States & $\begin{array}{l}\text { Australia, Brunei Darussalam, } \\
\text { Canada, Chile, Japan, } \\
\text { Malaysia, Mexico, } \\
\text { New Zealand, Peru, } \\
\text { Singapore, and Viet Nam }\end{array}$ & $\begin{array}{l}\text { Australia, Brunei Darussalam, } \\
\text { Cambodia, the PRC, Indonesia, } \\
\text { Japan, the Republic of Korea, the } \\
\text { Lao People's Democratic Republic, } \\
\text { Malaysia, Myanmar, New Zealand, } \\
\text { the Philippines, Singapore, } \\
\text { Thailand, and Viet Nam }\end{array}$ \\
\hline Launch date & 2019 & 2018 & 2020 \\
\hline Tariff liberalization & $\begin{array}{l}\text { As per Phase I US-PRC } \\
\text { agreement of December } \\
2019\end{array}$ & $\begin{array}{l}\text { As negotiated for } \\
\text { Trans- Pacific } \\
\text { Partnership (TPP) } \\
\text { agreement }\end{array}$ & $90 \%$ eliminated \\
\hline
\end{tabular}

6 For more details of the CGE model employed see Petri, Plummer, and Zhai (2012) and Petri and Plummer (2016).

7 The model does not account for corresponding changes in leisure or nonmarket activity. 
Table 2 continued

\begin{tabular}{|c|c|c|c|}
\hline & $\begin{array}{l}\text { PRC-US } \\
\text { Trade War }\end{array}$ & СРТРP & RCEP \\
\hline $\begin{array}{l}\text { Nontariff barrier } \\
\text { liberalization } \\
\text { Agricultural } \\
\text { liberalization } \\
\text { Services liberalization }\end{array}$ & $\begin{array}{l}\text { PRC-US nontariff barriers } \\
\text { up } 10 \% \\
\text { Most US-PRC nontariff } \\
\text { barriers up } 10 \% \\
\text { US-PRC tech nontariff } \\
\text { barriers up } 50 \%\end{array}$ & \multirow[t]{2}{*}{$\begin{array}{l}\text { As negotiated for TPP } \\
\text { agreement except for } \\
\text { suspended provisions }\end{array}$} & \multirow[t]{2}{*}{$\begin{array}{l}\text { Average of recent ASEAN+1 } \\
\text { agreements }\end{array}$} \\
\hline $\begin{array}{l}\text { Foreign direct } \\
\text { investment liberalization }\end{array}$ & US-PRC barriers doubled & & \\
\hline $\begin{array}{l}\text { Non-preferential, } \\
\text { nontariff barrier } \\
\text { reductions }\end{array}$ & None & $10 \%$ & $10 \%$ \\
\hline
\end{tabular}

ASEAN = Association of Southeast Asian Nations, CPTPP $=$ Comprehensive and Progressive Agreement for Trans-Pacific Partnership, NTB $=$ nontariff barrier, $\mathrm{PRC}=$ People's Republic of China, RCEP = Regional Comprehensive Economic Partnership, US = United States.

Source: Authors.

The assumptions and parameters used to quantify the three scenarios are in Table 2. The PRC-US Trade War assumes that tariffs and nontariff barriers reached under the PRC-US Phase One agreement in January 2020 are here to stay at least through 2030. The CPTPP assumes tariff schedules negotiated in the CPTPP and nontariff barriers achieved under similar high-quality trade agreements (mainly the Republic of Korea-US and NAFTA agreements). These are assumed to be implemented gradually starting from the agreement's entry into force in 2018. The RCEP assumes parameter changes that reflect data and judgments based on the published agreement. Average tariff reductions conform to the $90 \%$ average tariff elimination announced at the conclusion of the RCEP. Product-specific changes are based on judgments rather than actual tariff schedule details, which were not available when these simulations were run. They will be incorporated in an update. Similarly, RCEP nontariff barriers are based on general text provisions and will be updated as details on flexibilities are processed.

\section{ESTIMATES OF THE EFFECTS OF THE REGIONAL COMPREHENSIVE ECONOMIC PARTNERSHIP AND OTHER POLICIES}

The simulations reported below assess the effects of successively adding the PRC-US trade war, and the CPTPP and RCEP agreements to a baseline growth path under policies prevailing in $2015 .{ }^{8}$ This sequential modeling approach enables us to assess how each policy contributes to overall changes in the current policy environment-for example, to what extent increases in East Asian interdependence can be attributed to PRC-US tensions and to trade liberalization under the CPTPP and RCEP agreements.

8 Using a similar model, but without endogenous labor effects and with a different template for RCEP, we also estimate (in Petri and Plummer 2020) a scenario in which PRC-US trade policies revert to the status quo prior to the trade war. That outcome appears increasingly unlikely today. 


\section{A. Aggregate Income and Trade Effects of Major Policy Changes}

The economic impact of the three policy scenarios is summarized in Table 3 for real domestic incomes and in Table 4 for exports. These tables show effects in incremental terms, that is, the amount that each scenario adds to (or subtracts from) previous policies. The first column of Table 3 shows how the trade war changes incomes from baseline projections for 2030. Subsequent scenarios then assume that the trade war remains in place; the second and third columns show how the CPTPP and RCEP agreements, respectively, further change incomes.

Table 3: Income Effects of Asia and the Pacific Policies

\begin{tabular}{|c|c|c|c|c|c|c|c|}
\hline & \multirow[b]{2}{*}{2030 Income } & \multicolumn{3}{|c|}{$\begin{array}{l}\text { Incremental Income } \\
\text { (\$ billion) }\end{array}$} & \multicolumn{3}{|c|}{$\begin{array}{c}\text { Percent Income Change } \\
(\%)\end{array}$} \\
\hline & & $\begin{array}{l}\text { PRC-US } \\
\text { Trade War }\end{array}$ & СРТРP & RCEP & $\begin{array}{l}\text { PRC-US } \\
\text { Trade War }\end{array}$ & СРTPP & RCEP \\
\hline Americas & 39,569 & 6 & 60 & 3 & 0.01 & 0.15 & 0.01 \\
\hline Canada & 2,717 & 6 & 26 & 1 & 0.23 & 0.96 & 0.02 \\
\hline Chile & 463 & -1 & 4 & 0 & -0.18 & 0.82 & 0.03 \\
\hline Colombia & 684 & 1 & 0 & 0 & 0.12 & 0.00 & 0.03 \\
\hline Mexico & 2,169 & 29 & 21 & 1 & 1.33 & 0.98 & 0.03 \\
\hline Peru & 442 & 1 & 12 & 0 & 0.16 & 2.64 & 0.00 \\
\hline United States & 25,754 & -41 & -4 & 0 & -0.16 & -0.01 & 0.00 \\
\hline Latin America nie & 7,341 & 11 & 1 & 1 & 0.14 & 0.01 & 0.01 \\
\hline Asia & 50,659 & -490 & 91 & 234 & -0.97 & 0.18 & 0.46 \\
\hline Brunei Darussalam & 31 & 0 & 1 & 0 & -1.28 & 3.01 & 0.53 \\
\hline China, People's Republic of & 27,839 & -515 & -14 & 127 & -1.85 & -0.05 & 0.46 \\
\hline Hong Kong, China & 461 & -25 & 2 & 2 & -5.42 & 0.38 & 0.42 \\
\hline India & 5,487 & 17 & -5 & -7 & 0.31 & -0.09 & -0.13 \\
\hline Indonesia & 2,192 & 3 & -2 & 4 & 0.15 & -0.09 & 0.18 \\
\hline Japan & 4,924 & 7 & 57 & 60 & 0.13 & 1.17 & 1.22 \\
\hline Korea, Republic of & 2,243 & 7 & -4 & 28 & 0.31 & -0.16 & 1.27 \\
\hline Malaysia & 675 & 4 & 29 & 7 & 0.60 & 4.36 & 1.03 \\
\hline Philippines & 680 & 3 & 0 & 3 & 0.43 & -0.05 & 0.39 \\
\hline Singapore & 485 & -3 & 15 & 0 & -0.70 & 3.14 & 0.05 \\
\hline Taipei,China & 776 & 0 & 0 & -4 & -0.04 & -0.02 & -0.47 \\
\hline Thailand & 812 & 6 & -5 & 7 & 0.68 & -0.67 & 0.88 \\
\hline Viet Nam & 497 & 5 & 17 & 5 & 1.01 & 3.38 & 0.97 \\
\hline ASEAN nie & 283 & 1 & 0 & 2 & 0.29 & -0.06 & 0.56 \\
\hline Asia nie & 3,272 & 2 & 0 & 0 & 0.07 & 0.00 & 0.01 \\
\hline Oceania & 2,854 & -2 & 19 & 2 & -0.07 & 0.65 & 0.08 \\
\hline Australia & 2,590 & -2 & 15 & 2 & -0.09 & 0.58 & 0.06 \\
\hline New Zealand & 264 & 0 & 4 & 1 & 0.06 & 1.38 & 0.28 \\
\hline
\end{tabular}




\begin{tabular}{|c|c|c|c|c|c|c|c|}
\hline & \multirow[b]{2}{*}{2030 Income } & \multicolumn{3}{|c|}{$\begin{array}{l}\text { Incremental Income } \\
\text { (\$ billion) }\end{array}$} & \multicolumn{3}{|c|}{$\begin{array}{c}\text { Percent Income Change } \\
(\%)\end{array}$} \\
\hline & & $\begin{array}{l}\text { PRC-US } \\
\text { Trade War }\end{array}$ & СРTPP & RCEP & $\begin{array}{l}\text { PRC-US } \\
\text { Trade War }\end{array}$ & CPTPP & RCEP \\
\hline Rest of the World & 40,720 & -28 & 19 & 24 & -0.07 & 0.05 & 0.06 \\
\hline Africa (Sub-Sahara) & 4,068 & 4 & 0 & 1 & 0.09 & 0.00 & 0.01 \\
\hline Europe & 23,189 & -12 & 14 & 14 & -0.05 & 0.06 & 0.06 \\
\hline EMENA & 10,001 & -17 & 4 & 7 & -0.17 & 0.04 & 0.07 \\
\hline Russian Federation & 3,371 & -3 & 1 & 2 & -0.09 & 0.02 & 0.04 \\
\hline Others & 90 & 0 & 0 & 0 & 0.52 & 0.12 & 0.11 \\
\hline WORLD & 133,801 & -514 & 188 & 263 & -0.38 & 0.14 & 0.20 \\
\hline \multicolumn{8}{|l|}{ Memorandum } \\
\hline RCEP15 members & 43,516 & -486 & 113 & 245 & -1.10 & 0.30 & 0.60 \\
\hline
\end{tabular}

Table 4: Export Effects of Asia and the Pacific Policies

\begin{tabular}{lrrrrrrr}
\hline & & \multicolumn{2}{c}{$\begin{array}{c}\text { Incremental Exports } \\
\text { (\$ billion) }\end{array}$} & \multicolumn{4}{c}{$\begin{array}{c}\text { Percent Export Change } \\
\text { (\%) }\end{array}$} \\
\cline { 3 - 8 } & $\begin{array}{c}2030 \\
\text { Exports }\end{array}$ & $\begin{array}{c}\text { PRC-US } \\
\text { Trade War }\end{array}$ & CPTPP & RCEP & $\begin{array}{c}\text { PRC Trade } \\
\text { War }\end{array}$ & CPTPP & RCEP \\
\hline Americas & 7,068 & -379 & 78 & -4 & -5.4 & 1.1 & -0.1 \\
\hline Canada & 835 & 8 & 40 & -1 & 1.0 & 4.8 & -0.1 \\
Chile & 147 & -2 & 6 & -1 & -1.2 & 4.4 & -0.4 \\
Colombia & 120 & -1 & 0 & 0 & -0.5 & 0.1 & 0.0 \\
Mexico & 670 & 32 & 25 & -1 & 4.8 & 3.8 & -0.2 \\
Peru & 135 & -1 & 12 & 0 & -0.6 & 9.2 & -0.2 \\
United States & 3,906 & -411 & -8 & -2 & -10.5 & -0.2 & -0.1 \\
Latin America nie & 1,255 & -6 & 2 & 1 & -0.4 & 0.1 & 0.1 \\
\hline Asia & 12,905 & -522 & 187 & 496 & -4.0 & 1.4 & 3.8 \\
\hline Brunei Darussalam & 16 & 0 & 1 & 0 & -1.6 & 3.6 & 0.6 \\
China, People's Republic of & 4,976 & -506 & -6 & 234 & -10.2 & -0.1 & 4.7 \\
Hong Kong, China & 357 & -11 & 1 & -1 & -3.0 & 0.3 & -0.4 \\
India & 1,360 & 0 & -3 & -5 & 0.0 & -0.2 & -0.4 \\
Indonesia & 446 & -2 & -3 & 13 & -0.5 & -0.6 & 2.8 \\
Japan & 1,190 & 0 & 100 & 133 & 0.0 & 8.4 & 11.2 \\
Korea, Republic of & 1,089 & 0 & -6 & 65 & 0.0 & -0.5 & 6.0 \\
\hline
\end{tabular}




\begin{tabular}{|c|c|c|c|c|c|c|c|}
\hline & \multirow[b]{2}{*}{$\begin{array}{l}2030 \\
\text { Exports }\end{array}$} & \multicolumn{3}{|c|}{$\begin{array}{l}\text { Incremental Exports } \\
\qquad(\$ \text { billion })\end{array}$} & \multicolumn{3}{|c|}{$\begin{array}{l}\text { Percent Export Change } \\
(\%)\end{array}$} \\
\hline & & $\begin{array}{l}\text { PRC-US } \\
\text { Trade War }\end{array}$ & CPTPP & RCEP & $\begin{array}{l}\text { PRC Trade } \\
\text { War }\end{array}$ & CPTPP & RCEP \\
\hline Malaysia & 491 & 3 & 45 & 12 & 0.7 & 9.3 & 2.5 \\
\hline Philippines & 184 & 1 & 0 & 7 & 0.7 & -0.1 & 3.7 \\
\hline Singapore & 470 & -2 & 30 & -2 & -0.4 & 6.4 & -0.5 \\
\hline Taipei,China & 506 & -4 & 0 & -8 & -0.8 & 0.0 & -1.5 \\
\hline Thailand & 561 & 3 & -7 & 28 & 0.6 & -1.2 & 4.9 \\
\hline Viet Nam & 357 & 2 & 35 & 16 & 0.4 & 9.7 & 4.4 \\
\hline Other ASEAN & 93 & 0 & 0 & 4 & -0.1 & -0.5 & 4.5 \\
\hline Asia nie & 810 & -7 & 1 & 1 & -0.9 & 0.1 & 0.1 \\
\hline Oceania & 673 & -10 & 29 & 4 & -1.4 & 4.3 & 0.6 \\
\hline Australia & 589 & -9 & 24 & 3 & -1.5 & 4.0 & 0.6 \\
\hline New Zealand & 84 & -1 & 5 & 1 & -0.9 & 5.9 & 1.2 \\
\hline Rest of the World & 15,503 & -143 & 19 & 0 & -0.9 & 0.1 & 0.0 \\
\hline Africa (Sub-Sahara) & 883 & -6 & 1 & 1 & -0.7 & 0.1 & 0.1 \\
\hline Europe & 9,706 & -76 & 10 & -6 & -0.8 & 0.1 & -0.1 \\
\hline EMENA & 4,021 & -52 & 6 & 4 & -1.3 & 0.1 & 0.1 \\
\hline Russian Federation & 851 & -9 & 1 & 1 & -1.0 & 0.1 & 0.1 \\
\hline Others & 43 & 0 & 0 & 0 & -0.7 & 0.4 & -0.1 \\
\hline WORLD & 36,149 & $-1,053$ & 312 & 496 & -2.9 & 0.9 & 1.4 \\
\hline \multicolumn{8}{|l|}{ Memorandum } \\
\hline RCEP15 members & 10,545 & -510 & 217 & 514 & -4.8 & 2.1 & 4.9 \\
\hline
\end{tabular}

ASEAN = Association of Southeast Asian Nations; CPTPP = Comprehensive and Progressive Agreement for Trans-Pacific Partnership; EMENA = Europe, Middle East, and North Africa; nie = not included elsewhere; Other ASEAN = Cambodia, the Lao People's Democratic Republic, and Myanmar; PRC = People's Republic of China; RCEP = Regional Comprehensive Economic Partnership; US = United States. Source: Authors' simulations.

With respect to global income effects (World sum in Table 3), the trade war is the most significant of the three scenarios, reducing global incomes by $\$ 514$ billion, or $0.38 \%$. The CPTPP then adds $\$ 188$ billion back to world incomes, and RCEP adds a further $\$ 263$ billion. Thus, the RCEP has greater impact than the CPTPP, especially for RCEP member countries. The two agreements together come close to offsetting the negative effects of the trade war on global incomes.

Income effects vary substantially across economies (Table 3). The losses from the trade war are most severely felt by the PRC ( $\$ 515$ billion) and the United States ( $\$ 41$ billion), and neither the CPTPP nor the RCEP offset these losses for either country. The largest gains from the CPTPP flow mainly to Japan, Malaysia, Viet Nam and Singapore, and some North American countries, while those from the RCEP flow to the PRC, Japan, the Republic of Korea and, in \% terms, to several Southeast Asian economies. For the PRC, the gains from the RCEP ( $\$ 127$ billion) cover only about one-quarter of 
the losses imposed by the trade war. Most other East Asian countries, however, are in the end well ahead from results projected under the baseline scenario.

Trade effects follow similar patterns with interesting differences (Table 4). Again, the PRC and the United States suffer the most significant losses from the trade war, which reduces US trade ( $-\$ 411$ billion) nearly as much as PRC trade ( $\$ 506$ billion). However, the PRC will recapture almost half of these losses through RCEP, while the United States suffers trade diversion from both new agreements (it is neither a member of the CPTPP nor RCEP). Malaysia, Thailand, and Viet Nam gain marginally from the trade war and substantially from the CPTPP and RCEP.

These results are similar to those in two other recent studies of the CPTPP and RCEP agreements. Ferrantino, Maliszewska, and Taran (2020) use the World Bank's LINKAGE model and report aggregate income gains for the CPTPP as $0.4 \%$ of members' incomes, and for RCEP (including India) as $1.5 \%$ of members' incomes. The Monetary Authority of Singapore (2021) reports gains based on tariff reductions from RCEP (excluding India) at $0.4 \%$ of the members' gross domestic product after 10 years but notes that the RCEP's rules of origin would add substantial additional value. In this study, the income effects of the CPTPP are projected to be $1.1 \%$ of the incomes of members and of the RCEP (excluding India) to be $0.6 \%$ of the incomes of members (Table 3 ).

\section{B. Labor Market Implications of Trade Policy Developments}

Popular discussions of trade policy often emphasize a job creation objective, even though economic models seldom attribute long-run employment effects to trade policies. Regardless of trade policy, an economy can achieve normal employment of labor endowments in the long run through market forces and/or macroeconomic policies (Krugman 1993). The benefits of trade policy instead reflect shifts in employment from low-productivity to high-productivity jobs. However, as this happens, trade agreements can raise real wages and, in some cases, especially low-income economies, wage changes will induce workers to enter or leave formal labor markets and thus change labor endowments. As noted, given the potential relevance of this mechanism to the RCEP, this study endogenizes skilled and unskilled labor supplies by relating changes in their levels to projected changes in real wages.

To examine the results of this mechanism, projected values of real wage changes are summarized in Figure 1. Real wage changes generally correspond to changes in incomes reported in Table 3, but are typically larger. The trade war scenario (first bar in Figure 1) depresses wages, especially for the PRC, the US, and their close trade partners. It raises wages in a few economies, such as Viet Nam, that benefit because they compete with the PRC or the US. The CPTPP (second bar) and RCEP (third bar) scenarios increase skilled wages for RCEP members by $1.3 \%$ and $1.1 \%$, respectively. These wage effects are especially high for trade-dependent economies like Viet Nam, increasing skilled wages there by $6.0 \%$ and $2.3 \%$, respectively. Unskilled wage changes are distributed similarly across economies but are smaller in magnitude. 


\section{Figure 1: Real Returns to Labor under Asia and the Pacific Policies}

(\% Changes in 2030)

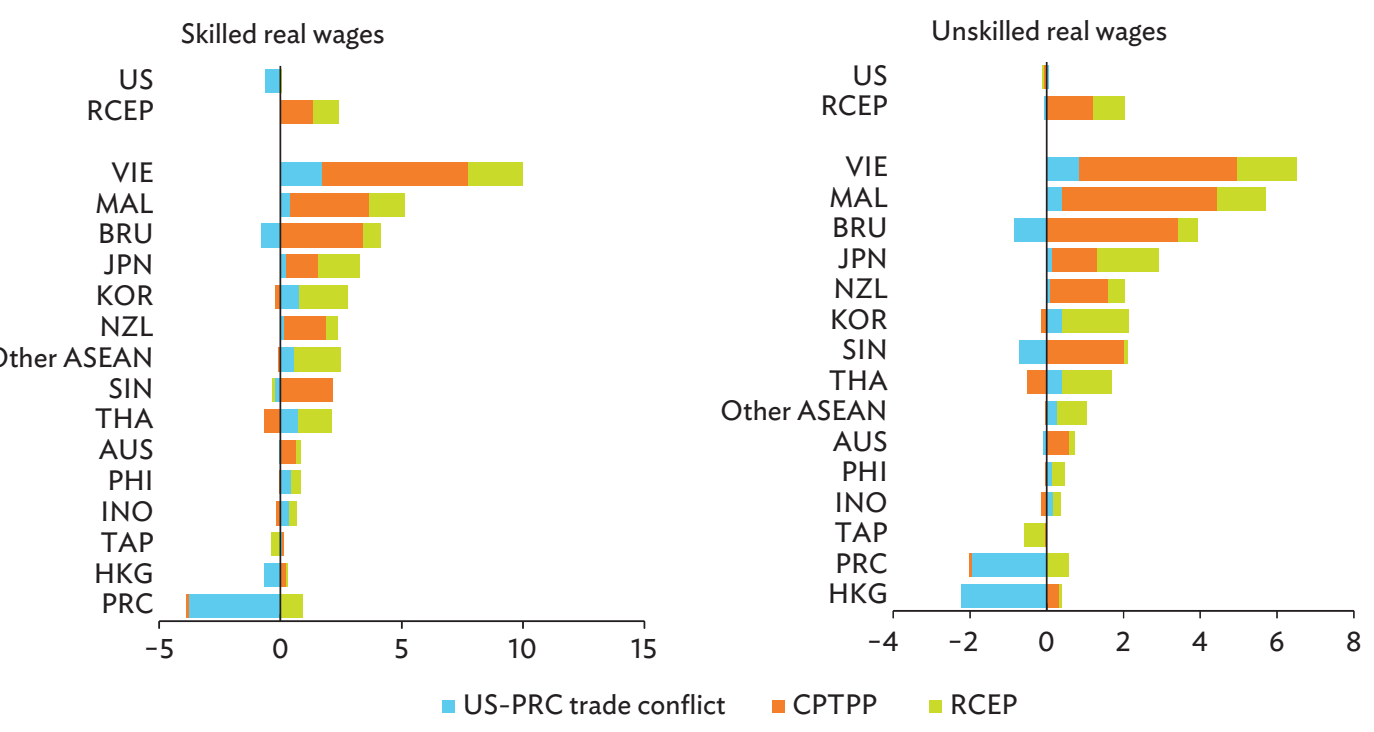

ASEAN = Association of Southeast Asian Nations; AUS = Australia; BRU = Brunei Darussalam; CPTPP = Comprehensive and Progressive Agreement on Trans-Pacific Partnership; HKG = Hong Kong, China; INO = Indonesia; JPN = Japan; KOR = Republic of Korea; MAL = Malaysia; NZL = New Zealand; Other ASEAN = Cambodia, the Lao People's Democratic Republic, and Myanmar; $\mathrm{PHI}=$ Philippines; PRC = People's Republic of China; RCEP15 = Regional Comprehensive Economic Partnership (15 members); SIN = Singapore; TAP = Taipei,China; THA = Thailand; VIE = Viet Nam; US = United States.

Source: Authors' calculations.

The employment effects of the scenarios are reported in Figure 2. The trade war (first bar) by itself will affect global employment negatively ( -3 million jobs), but will be offset by increases of 1.5 million and 2.6 million jobs created by the CPTPP (second bar) and RCEP (third bar), respectively. The PRC will be especially hard hit by the trade war ( -4.8 million jobs) and to a lesser extent by the CPTPP (-159,000), but it will gain 1.4 million jobs due to the RCEP. India will gain jobs $(678,000)$ due to the trade war but lose nearly all $(438,000)$ as a result of the CPTPP and RCEP. Viet Nam will achieve the largest percentage increases from the three scenarios combined (1.8 million jobs), reflecting its competitive position relative to the PRC and its membership in both the CPTPP and RCEP agreements. Malaysia, Japan, and New Zealand will have smaller, but also positive gains from the combined policy changes. 


\section{Figure 2: Employment Effects under Asia and the Pacific Policies}

(\% of 2030 Baseline Employment)
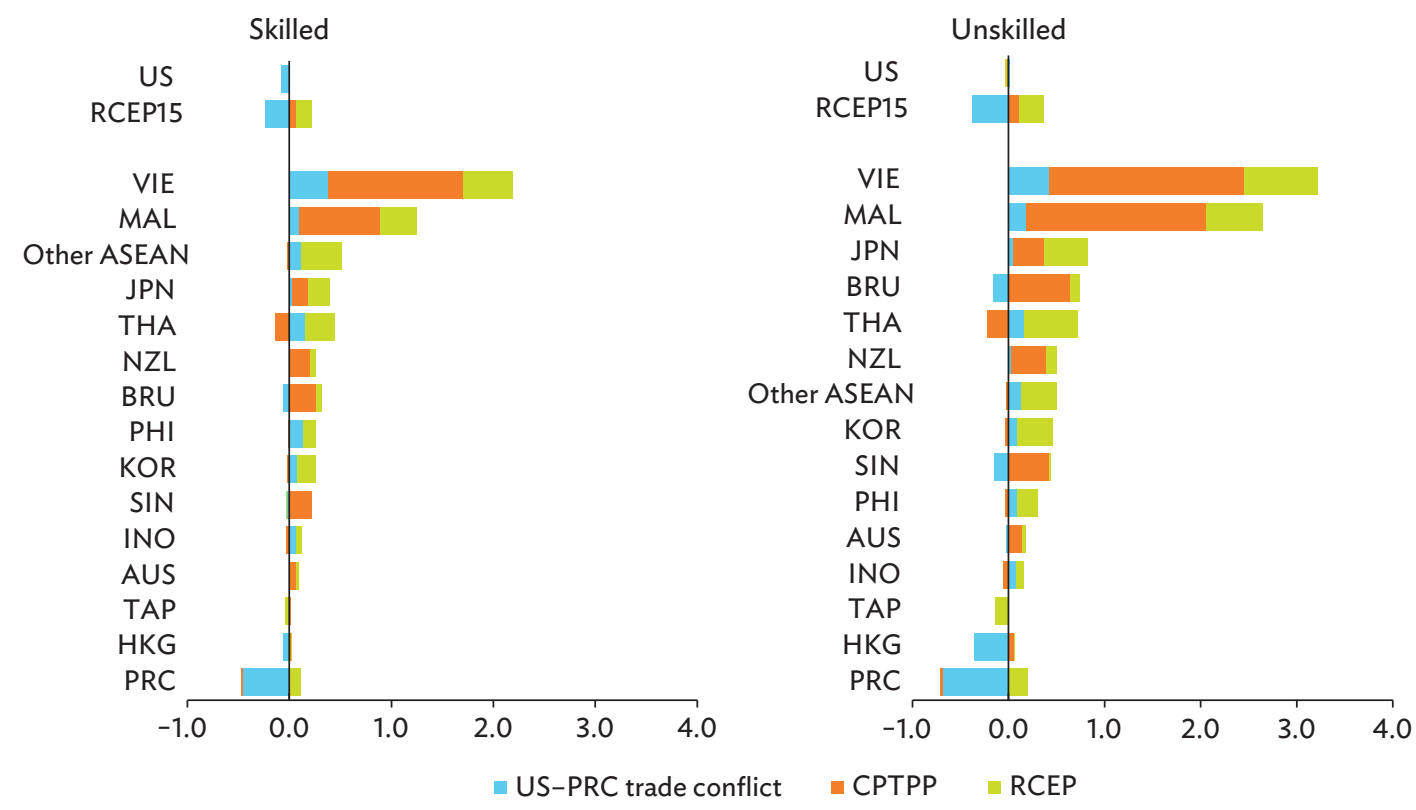

ASEAN = Association of Southeast Asian Nations; AUS = Australia; BRU = Brunei Darussalam; CPTPP $=$ Comprehensive and Progressive Agreement on Trans-Pacific Partnership; HKG = Hong Kong, China; INO = Indonesia; JPN = Japan; KOR = Republic of Korea; MAL = Malaysia; NZL = New Zealand; Other ASEAN = Cambodia, the Lao People's Democratic Republic, and Myanmar; PHI = Philippines; $\mathrm{PRC}=$ People's Republic of China; RCEP15 = Regional Comprehensive Economic Partnership (15 members); SIN = Singapore; TAP = Taipei, China; THA = Thailand; VIE = Viet Nam; US = United States.

Notes: Estimated employment based on global employment data sources. Division into skilled and unskilled employment based on CGE model. Skilled and unskilled employment increases based on RCEP model simulation. Other ASEAN includes Cambodia, the Lao People's Democratic Republic, and Myanmar.

Source: Authors' calculations.

\section{Sources of Income and Trade Gains}

The results in this paper-including those already reported above-ultimately depend on the changes in trade barriers operating in the model. These are derived from the trade policy provisions outlined in Tables 1 and 2, translated into quantitative tariff and nontariff barriers (expressed in terms of ad valorem tariff equivalents) in the model. With simulations of different subsets of changes, it is also possible to pinpoint the source of aggregate effects-that is, how individual policy changes that account for overall income and trade gains.

We begin by examining how barriers that apply to intra-RCEP trade will change under the three policy scenarios in Table 5. This table shows the barriers that RCEP members apply to goods imported from other RCEP partners. Baseline values-what these barriers would be in 2030 without policy changes - are in the initial columns of the sections of Table 5 that show tariff, nontariff, and total barriers. The next two columns in these sections show how barriers will be changed by the CPTPP (policy actions by those RCEP members that are also members in the CPTPP) and by the RCEP. There is no column for changes due to the trade war, since the policy changes in the scenario only apply to PRC-US trade, which is not intra-RCEP trade. Of course, those changes too will ultimately affect significantly global trade, including trade among RCEP members. 
As the last line of Table 5 indicates, the average tariffs applied to intra-RCEP trade would be $3.1 \%$ in 2030 on the baseline, and would fall by $0.3 \%$ and 1.2 under the CPTPP and RCEP, or by a total $1.5 \%$. Nontariff barriers would be $10.2 \%$ on the baseline and would fall by a total of $1.1 \%$. Thus, total barriers (the sum of tariffs and nontariff barriers) would be $13.3 \%$ and fall by a total of $2.7 \%$. Note that tariff reductions are larger than nontariff barrier reductions overall even though initial nontariff barriers are higher than tariffs; nontariff barriers are notoriously hard to cut and negotiations in a diverse context often make more progress on tariffs than on nontariff issues.

Table 5: Barriers Applied to the Regional Comprehensive Economic Partnership Exports in Intra-RCEP Trade, by Exporter

(Unweighted Percentage Points in 2030)

\begin{tabular}{|c|c|c|c|c|c|c|c|c|c|}
\hline \multirow[b]{2}{*}{ Exporter } & \multicolumn{3}{|c|}{ Tariffs } & \multicolumn{3}{|c|}{ Nontariff Barriers } & \multicolumn{3}{|c|}{ Total Barriers } \\
\hline & Baseline & $\triangle$ CРТPР & $\triangle \mathrm{RCEP}$ & Baseline & $\triangle$ CРТPР & $\triangle \mathrm{RCEP}$ & Baseline & $\triangle$ CPTPP & $\triangle \mathrm{RCEP}$ \\
\hline $\begin{array}{l}\text { China, People's } \\
\text { Republic of }\end{array}$ & 3.0 & 0.0 & -1.0 & 8.8 & -0.1 & -0.7 & 11.8 & -0.1 & -1.7 \\
\hline Japan & 3.2 & -0.6 & -1.3 & 10.5 & -0.8 & -1.3 & 13.7 & -1.3 & -2.6 \\
\hline Korea, Rep. of & 2.3 & 0.0 & -1.0 & 10.3 & -0.1 & -1.0 & 12.7 & -0.1 & -2.0 \\
\hline Brunei & 0.4 & -0.1 & -0.1 & 15.2 & -1.0 & -0.4 & 15.6 & -1.0 & -0.5 \\
\hline Indonesia & 3.4 & 0.0 & -1.5 & 10.4 & 0.0 & -0.3 & 13.8 & 0.0 & -1.7 \\
\hline Malaysia & 1.0 & -0.2 & -0.3 & 10.3 & -0.4 & -0.3 & 11.3 & -0.6 & -0.5 \\
\hline Philippines & 1.6 & 0.0 & -0.6 & 10.4 & 0.0 & -0.3 & 11.9 & 0.0 & -0.9 \\
\hline Singapore & 2.1 & -0.3 & -0.6 & 9.1 & -0.3 & 0.0 & 11.2 & -0.6 & -0.6 \\
\hline Thailand & 3.1 & 0.0 & -1.3 & 10.3 & 0.0 & -0.3 & 13.4 & 0.0 & -1.6 \\
\hline Viet Nam & 2.5 & -0.2 & -0.9 & 10.2 & -0.5 & -0.3 & 12.7 & -0.7 & -1.2 \\
\hline Other ASEAN & 2.7 & 0.0 & 0.0 & 15.0 & -0.3 & -0.2 & 17.7 & -0.3 & -0.2 \\
\hline Australia & 2.9 & -0.7 & -0.8 & 9.1 & -0.3 & 0.0 & 12.0 & -1.0 & -0.8 \\
\hline New Zealand & 6.8 & -0.6 & -3.2 & 12.0 & -1.3 & -0.8 & 18.8 & -1.9 & -4.0 \\
\hline RCEP Average & 3.1 & -0.3 & -1.2 & 10.2 & -0.4 & -0.7 & 13.3 & -0.7 & -2.0 \\
\hline
\end{tabular}

ASEAN = Association of Southeast Asian Nations, CPTPP = Comprehensive and Progressive Agreement on Trans-Pacific Partnership, RCEP = Regional Comprehensive Economic Partnership.

Note: The trade war scenario only affects barriers between the People's Republic of China and the United States and is not included among intra-RCEP barriers.

Source: Authors' simulations.

The barriers applied to Northeast Asia's three large economies-the PRC, Japan, and the Republic of Korea-are among those that decline the most, since RCEP will be the first trade agreement that fully spans these countries (Table 5). In fact, given the large volume of trade among them, weighted average reductions, unlike the unweighted averages calculated in Table 5, would show even greater declines. By contrast, intra-RCEP barriers against the exports of ASEAN economies are generally smaller on the baseline and fall relatively little, since these reflect relatively deep prior reductions through existing trade agreements. 
What parts of the agreements are most responsible for its overall impact? We can look "inside" each trade scenario by simulating the effects of different liberalization instruments as if they were applied individually. Figure 3 thus decomposes the global income effects of RCEP by instrumentspecifically changes in tariffs, nontariff barriers in goods and in services, cumulative rules of origin, and barriers to investment.

\section{Figure 3: Composition of Global Income Effects of the Regional Comprehensive Economic Partnership, by Liberalization Instrument}

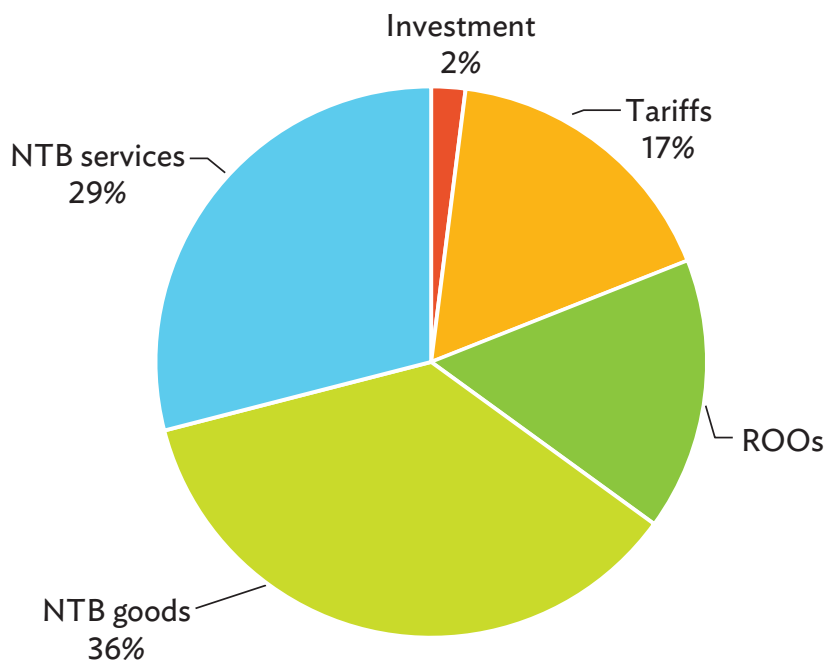

NTB $=$ nontariff barrier, RCEP $=$ Regional Comprehensive Economic Partnership, ROOs $=$ rules of origin. Source: Authors' calculations.

The striking implication of Figure 3 is that reductions in nontariff barriers drive the ultimate value added of RCEP agreement, accounting for about two-thirds of its total effects. The roles of tariffs and rules of origin at $17 \%$ and $16 \%$ are important, but more modest, and investment is only projected to contribute marginally (2\%). This finding is consistent with the long history of trade policy changes that have sharply reduced tariff barriers in recent decades but also created new layers of behind-the-border measures-including product standards, marketing and manufacturing regulations, and other administrative requirements - now associated with trade.

In contrast to global income, trade effects are dominated by changes in tariffs and rules of origin (Figure 4). The difference lies in the still-dominant role of goods in world trade, and particularly goods that have relatively low nontariff barriers. This effect is amplified by the extensive double-counting of intermediate goods involved in supply-chain trade. The outsized effect of tariffs on generating goods trade may also explain why tariffs and rules of origin receive so much interest from trade negotiators.

Since there is very little double-counting in services trade (these consists mostly of value added) the contribution of nontariff barriers on services is approximately the same in both income and trade accounts (Figures 3 and 4). In addition, services liberalization contributes to income even without trade, by stimulating productivity gains by domestic service providers. 


\section{Figure 4: Composition of the Global Trade Effects of the Regional Comprehensive Economic Partnership, by Liberalization Instrument}

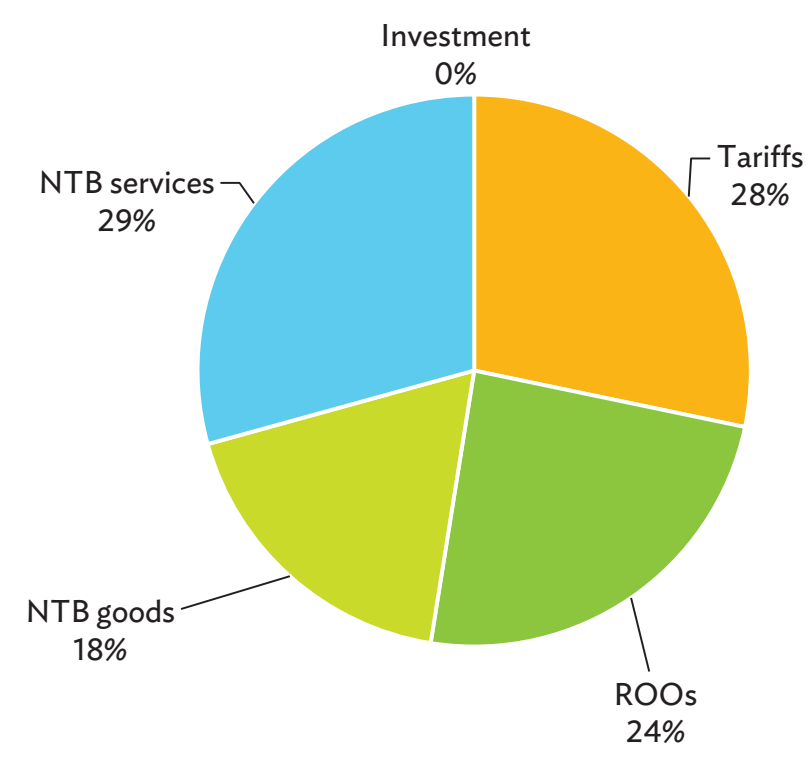

NTB $=$ nontariff barrier, RCEP $=$ Regional Comprehensive Economic Partnership, ROOs $=$ rules of origins.

Source: Authors' calculations.

The implication of Figures 3 and 4 is that realizing the agreement's full benefits will require sustained efforts to implement reductions in nontariff barriers to trade. Unlike tariff cuts, these barriers are hard to monitor-they require new approaches to control behind-the-border restrictions. These include active regional cooperation on trade facilitation, the development of consistent standards, mutual acceptance of certification, and so on. To drive these changes, the RCEP agreement created regular ministerial meetings and five joint committees. Using this mechanism will be critical to the agreement's success and will likely depend on leadership and public goods provided by the RCEP's largest Northeast Asian members. Their internal reforms and policies will set expectations for implementation throughout the region.

The results also suggest that benefits will depend mainly on the effective implementation of tariff cuts and the region's new, unified ROO framework. These can energize growth in regional manufacturing supply chains. Vigorous new supply chains will be important for Japan, the PRC, and the Republic of Korea, which have good opportunities to put specialized production advantages to work in combination with complementary inputs, and also for smaller countries and companies to help them connect to global markets and technologies.

\section{How Policy Changes Will Affect Trade Patterns}

The CPTPP and RCEP agreements will shift trade away from other partners toward members; taken together, the three policy scenarios should significantly accelerate East Asian economic integration. Figure 5 summarizes the effects of the three policy changes on overall trade by three major RCEP subregions: ASEAN, Oceania, and Northeast Asia (the PRC, Japan, the Republic of Korea). 
The largest effects are visible for the Northeast Asian economies, especially the PRC and Japan (note that the scale of the figure is 10 times as large as for the ASEAN and Oceania). PRC exports to non-RCEP economies will decline especially sharply ( $\$ 508$ billion), mainly due to the trade war with the United States. PRC also shows a substantial increase in trade with RCEP economies ( $\$ 231$ billion). PRC, Japanese, and Korean exports to RCEP partners increase especially as a result of the RCEP agreement. These effects are visible also for ASEAN and Oceania. However, the latter's export increases to nonRCEP countries are relatively large due to capturing some of PRC's trade, and to lower barriers CPTPP countries like Canada and Mexico. But even the CPTPP stimulates integration among RCEP membersfor example, it boosts Japanese trade with Malaysia and Viet Nam. It also results in some, albeit small, trade diversion for non-CPTPP countries in the region, including especially Indonesia and Thailand.

Figure 5: Export Changes under Asia and the Pacific Policies

(Changes in the Regional Comprehensive Economic Partnership Members' Exports in 2030, by Destination, $\$$ billion)
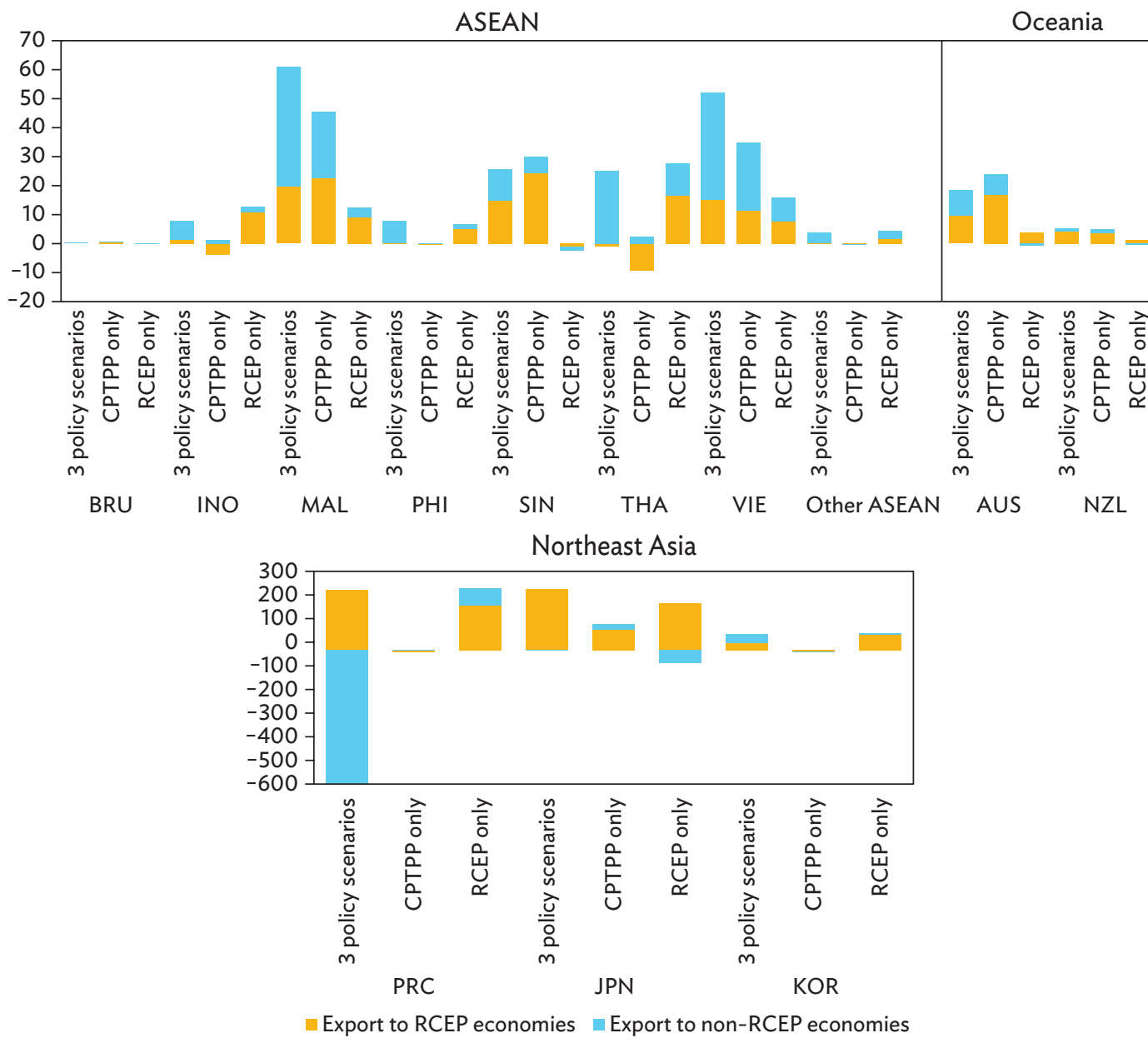

ASEAN = Association of Southeast Asian Nations; AUS = Australia; BRU = Brunei Darussalam; CPTPP = Comprehensive and Progressive

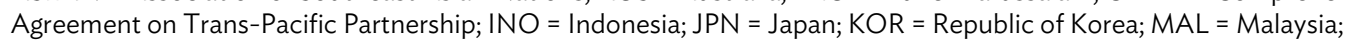

NZL = New Zealand; Other ASEAN = Cambodia, the Lao People's Democratic Republic, and Myanmar; PHI = Philippines;

PRC = People's Republic of China; RCEP = Regional Comprehensive Economic Partnership; SIN = Singapore; THA = Thailand;

$\mathrm{VIE}=$ Viet Nam; US = United States.

Note: The three policy scenarios refer to combined impact of US-PRC trade conflict, CPTPP, and RCEP on exports.

Source: Authors' calculations. 


\section{E. Sectoral Effects of Trade Policies}

The sectoral results offer further evidence on integration across the East Asian region, including through supply chains. To begin, Table 6 shows how tariffs and nontariff barriers will change on intra-RCEP trade, now disaggregated by products. (There is no column for the trade war scenario since it will not change intra-RCEP barriers.) The CPTPP and RCEP will reduce barriers by as much as one-third for manufacturing sectors, with a larger share of these cuts attributable to RCEP than to the CPTPP. Barriers tend to be highest on food-related production and services in the baseline and fall most on primary products. Tariffs and nontariff barriers on manufactured goods are relatively low on the baseline (always in single digits), but still fall significantly for manufactured goods like textiles, apparel, and vehicles. Both the CPTPP and RCEP lower intra-RCEP export barriers in virtually all sectors, with RCEP having greater impact on barriers in primary goods and services, in part due to its wider applicability across the region.

\section{Table 6: Barriers Applied to the Regional Comprehensive Economic Partnership Exports in Intra-RCEP Trade, by Sector}

(Unweighted Averages in 2030, Percentage Points)

\begin{tabular}{|c|c|c|c|c|c|c|c|c|c|}
\hline \multirow[b]{2}{*}{ Exporting Sector } & \multicolumn{3}{|c|}{ Tariffs } & \multicolumn{3}{|c|}{ Nontariff Barriers } & \multicolumn{3}{|c|}{ Total Protection } \\
\hline & Baseline & $\Delta$ CPTPP & $\triangle \mathrm{RCEP}$ & Baseline & $\Delta$ CPTPP & $\triangle \mathrm{RCEP}$ & Baseline & $\Delta$ CРTPP & $\triangle \mathrm{RCEP}$ \\
\hline Grains & 22.7 & -0.1 & -11.3 & 14.0 & -0.5 & -1.3 & 36.7 & -0.5 & -12.6 \\
\hline Other agriculture & 13.7 & -0.1 & -5.6 & 7.2 & -0.3 & -0.5 & 20.9 & -0.4 & -6.0 \\
\hline Mining & 1.1 & -0.1 & -0.4 & 1.8 & -0.1 & -0.1 & 2.9 & -0.2 & -0.5 \\
\hline Food processing & 9.1 & -0.6 & -3.0 & 13.5 & -0.6 & -1.0 & 22.6 & -1.3 & -4.0 \\
\hline Textiles & 3.1 & -0.2 & -1.0 & 3.4 & -0.3 & -0.2 & 6.5 & -0.5 & -1.2 \\
\hline Apparel & 5.4 & -0.8 & -1.6 & 1.5 & -0.1 & -0.1 & 6.8 & -0.9 & -1.7 \\
\hline Chemicals & 2.0 & -0.2 & -0.6 & 4.1 & -0.3 & -0.2 & 6.1 & -0.5 & -0.8 \\
\hline Metals & 1.1 & -0.1 & -0.3 & 3.9 & -0.1 & -0.3 & 5.0 & -0.2 & -0.6 \\
\hline Vehicles & 4.1 & -0.4 & -1.2 & 1.8 & -0.1 & -0.1 & 5.9 & -0.5 & -1.3 \\
\hline Electrical equipment & 0.9 & 0.0 & -0.3 & 3.3 & -0.1 & -0.1 & 4.2 & -0.1 & -0.4 \\
\hline Machinery & 2.0 & -0.2 & -0.6 & 6.2 & -0.2 & -0.2 & 8.1 & -0.4 & -0.8 \\
\hline Other manufacturing & 2.4 & -0.2 & -0.6 & 3.1 & -0.1 & -0.2 & 5.4 & -0.3 & -0.9 \\
\hline Utilities & 0.0 & 0.0 & 0.0 & 0.8 & 0.0 & 0.0 & 0.8 & 0.0 & 0.0 \\
\hline Construction & 0.0 & 0.0 & 0.0 & 32.9 & -0.3 & -1.3 & 32.9 & -0.3 & -1.3 \\
\hline General services & 0.0 & 0.0 & 0.0 & 20.4 & -0.4 & -1.5 & 20.4 & -0.4 & -1.5 \\
\hline Communications & 0.0 & 0.0 & 0.0 & 20.7 & -0.9 & -0.8 & 20.7 & -0.9 & -0.8 \\
\hline Finance & 0.0 & 0.0 & 0.0 & 26.4 & -1.1 & -0.9 & 26.4 & -1.1 & -0.9 \\
\hline Private services & 0.0 & 0.0 & 0.0 & 25.3 & -0.9 & -0.7 & 25.3 & -0.9 & -0.7 \\
\hline Social services & 0.0 & 0.0 & 0.0 & 24.0 & -0.9 & -0.6 & 24.0 & -0.9 & -0.6 \\
\hline \multicolumn{10}{|l|}{ Export Groups } \\
\hline Primary goods & 11.7 & -0.2 & -5.1 & 9.1 & -0.4 & -0.7 & 20.8 & -0.6 & -5.8 \\
\hline Light manufactures & 3.6 & -0.4 & -1.1 & 2.6 & -0.1 & -0.2 & 6.2 & -0.5 & -1.3 \\
\hline Advanced manufactures & 2.0 & -0.2 & -0.6 & 3.9 & -0.2 & -0.2 & 5.9 & -0.4 & -0.8 \\
\hline Traded services & 0.0 & 0.0 & 0.0 & 23.2 & -0.8 & -1.0 & 23.2 & -0.8 & -1.0 \\
\hline Other services & 0.0 & 0.0 & 0.0 & 19.5 & -0.4 & -0.8 & 19.5 & -0.4 & -0.8 \\
\hline
\end{tabular}

CPTPP = Comprehensive and Progressive Agreement on Trans-Pacific Partnership, RCEP = Regional Comprehensive Economic Partnership. Note: The trade war scenario only affects barriers between the PRC and the US and is not included among intra-RCEP barriers.

Source: Authors' simulations. 
Export effects in broad sectors and major country groupings are summarized in Figure 6 . The clear outlier among the scenarios is the trade war, which has major negative effects on durable manufacturing in the PRC, accounting for the lion's share of the PRC's trade losses. To some degree, the trade war shifts to RCEP competitors, with ASEAN, Japan and the Republic of Korea all increasing exports. However, it also reduces exports of nondurable manufactures for all groupings, reflecting contracting import demand by the PRC. Services trade is also negatively affected, especially for ASEAN, Japan, and the Republic of Korea.

\section{Figure 6: Sectoral and Regional Export Effects of Asia and the Pacific Policies} (Export Changes in 2030, \$ billion)

(a) ASEAN

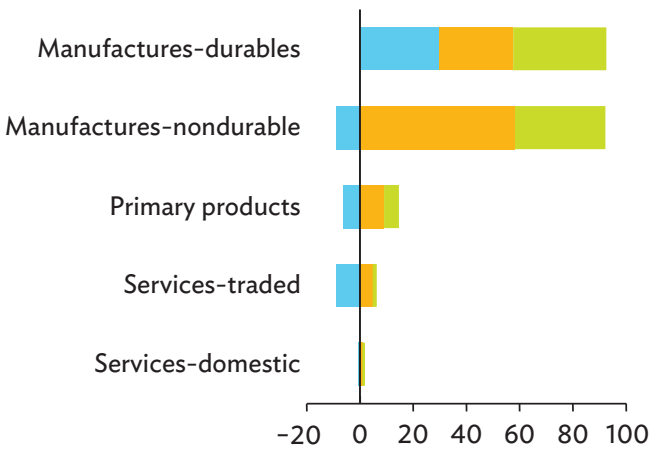

(c) Japan and the Republic of Korea

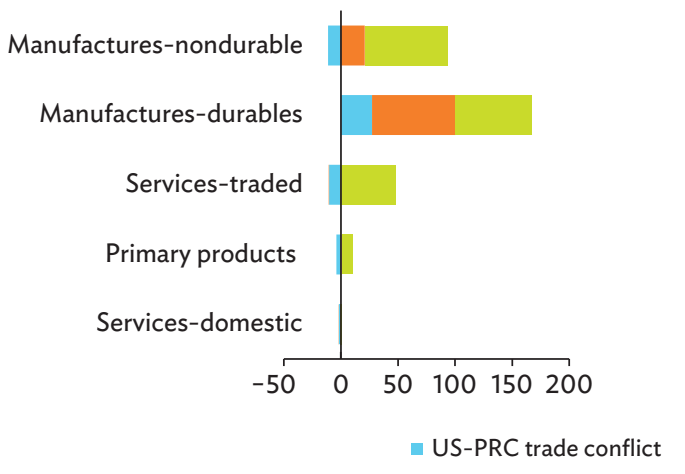

(b) PRC

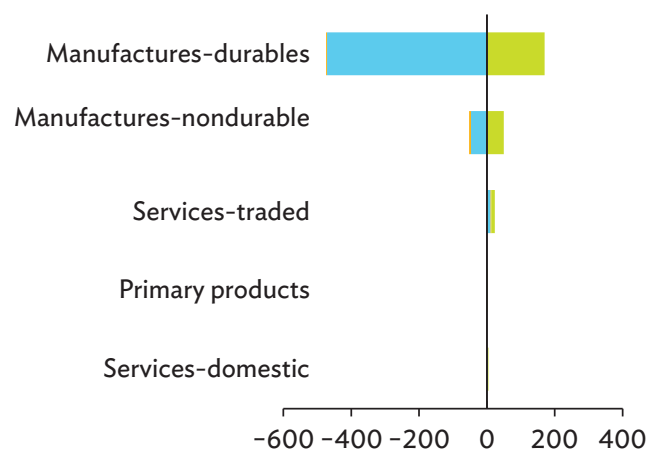

(d) Australia and New Zealand

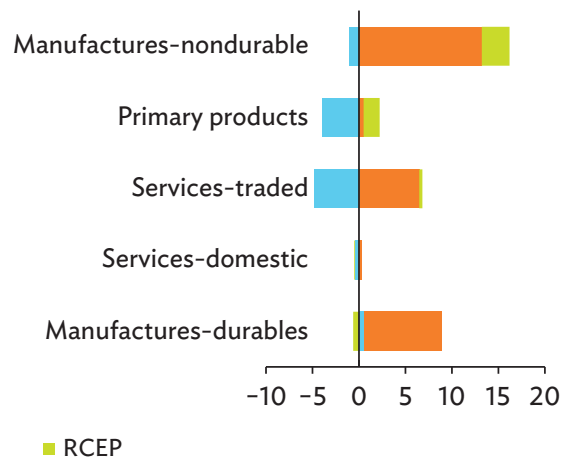

ASEAN = Association of Southeast Asian Nations; CPTPP = Comprehensive and Progressive Agreement on Trans-Pacific Partnership; PRC = People's Republic of China; RCEP = Regional Comprehensive Economic Partnership; US = United States.

Source: Authors' calculations.

Figure 6 also shows that the CPTPP and RCEP more than offset the effects of the trade war for RCEP members except the PRC. The CPTPP significantly raises exports of manufactures in every grouping within the RCEP region, including especially for Japan. RCEP produces similarly positive effects for all groups, with manufactures representing a high share of exports by ASEAN, Japan, and the Republic of Korea. The PRC experiences slight trade diversion in manufactures due to the CPTPP, but this effect is dwarfed by the positive effects of RCEP. Exports of traded services are significant mainly for Australia and New Zealand, mostly due to liberalization associated with the CPTPP. Primary products also play a modest role, benefiting Australia, New Zealand, and ASEAN. 
The dominant role of manufacturing in the sectoral results underlines the importance of new value chains across the RCEP region. A large share of the trade created by the CPTPP and RCEP focuses on manufactured products, consistent with other results on the central role of goods-related barriers and of ROO provisions in accounting for the RCEP's benefits. In a region well known for multiple zones of manufacturing excellence, the RCEP will provide a policy framework for further competition, deeper specialization, and wider support for globally competitive manufacturing. If the agreement is effectively implemented with attention to the interests of all participants, this new framework will not only benefit the manufacturing powerhouses of Northeast Asia but also help to energize globally competitive centers elsewhere in the region.

\section{CONCLUSION}

The goals of RCEP agreement are stipulated in the Agreement's first chapter:

(a) establish a modern, comprehensive, high-quality, and mutually beneficial economic partnership framework to facilitate the expansion of regional trade and investment and contribute to global economic growth and development, taking into account the stage of development and economic needs of the Parties especially of Least Developed Country Parties;

(b) progressively liberalise and facilitate trade in goods among the Parties through, inter alia, progressive elimination of tariff and nontariff barriers on substantially all trade in goods among the Parties;

(c) progressively liberalise trade in services among the Parties with substantial sectoral coverage to achieve substantial elimination of restrictions and discriminatory measures with respect to trade in services among the Parties; and

(d) create a liberal, facilitative, and competitive investment environment in the region, that will enhance investment opportunities and the promotion, protection, facilitation, and liberalisation of investment among the Parties.

In short, the RCEP agreement is dedicated to enhancing regional integration progressively, underscoring that the current accord is a work in progress. As noted above, ASEAN-centric agreements tend to improve over time, as reflected in several provisions of the RCEP agreement. Moreover, the RCEP is outward-oriented and explicitly inclusive: Chapter 20 confirms that, after an 18 -month waiting period, any economy could potentially enter negotiations to join.

This study shows that the benefits of the RCEP agreement could be substantial, particularly for Northeast Asia. While less comprehensive than the CPTPP, the RCEP is estimated to generate global income gains that are almost twice as great, due to its larger scale. Indeed, Japan, a member of both the CPTPP and RCEP, will gain as much from the latter as the former. Trade diversion will be minimal; with the most-affected economies of Taipei,China and India together losing $\$ 11$ billion, which is only $4 \%$ of the global gains that result from the agreement. At the sectoral level, exports and imports of nondurable and durable manufactures will experience the most growth. The CPTPP and RCEP will especially strengthen the region's manufacturing supply chains, raising productivity and increasing wages and employment. The RCEP will make East Asia a more formidable global competitor. 
Importantly, the RCEP is intended to serve as a stepping stone toward more comprehensive integration in Asia and the Pacific, much as the CPTPP served to stimulate the RCEP itself. While the RCEP is not as deep as the CPTPP, it deliberately left room for improvements. For example, it did not impose full disciplines on members at early stages of development by providing several flexibility clauses. But even the least developed members will begin to adopt the RCEP's framework once the agreement enters into force and, in time, will need to pursue its full for integration mandate.

This stepping-stone approach reflects the priorities outlined by Asia-Pacific Economic Cooperation (APEC) member economies at the APEC Summit in November 2010 in Yokohama, Japan. In charting a way toward a region of open trade and investment and a Free-Trade Area of the Asia-Pacific, APEC leaders envisioned two tracks: an Asia-Pacific track through the TPP, which had already started negotiations, and a broader Asian track, which would take less ambitious steps toward the same endpoint, a high-quality Free-Trade Area of the Asia-Pacific. This Asian track eventually became the RCEP. While much has changed since the 2010 Summit and the goal to start negotiations on the Free-Trade Area of the Asia-Pacific in 2020 has gone by, this part of the "Yokohama Vision" will be soon realized. 


\section{APPENDIX: DESCRIPTION OF THE COMPUTABLE GENERAL EQUILIBRIUM MODEL EMPLOYED}

\section{Overview of Model and System Parameters}

The simulations in this study use a 19-sector, 29-region computable general equilibrium (CGE) model of the world economy with a long track record. ${ }^{9}$ The model was initially developed by Zhai (2008) based on an early version of the World Bank's LINKAGE system (Van der Mensbrugghe 2011). However, it incorporates state-of-the-art production theory; it allows for monopolistic competition in some goods and services, and for firms operating with heterogeneous productivity levels within each sector. The model has been adapted to the analysis of free trade agreements and applied to Asia-Pacific economic integration in a variety of contexts (Petri, Plummer and Zhai, 2012; Petri and Plummer 2016, 2019, and 2020). Data are derived from the GTAP dataset and other information through 2015. Extensive additional data have been included in a sub-model that covers the structure of protection under nearly all trade agreements concluded in the Asia and the Pacific region, including the CPTPP and RCEP. ${ }^{10}$

Trade agreements are represented by five sets of parameters describing the structure of protection. These are the parameters varied in trade policy simulations:

- Tariffs

- Utilization rates of tariff preferences

- Nontariff barriers

- Costs associated with meeting rules of origin

- Barriers to foreign direct investment

The tariff reductions applied to trade flows are the product of the first two parameters, the reduction in preferential tariffs and the utilization rate of preferences. ${ }^{11}$ Nontariff barriers are introduced as tariff equivalents that result in higher costs for domestic goods and services. These are modeled in part as iceberg costs, that is, reductions in productivity, and in part as rents that are shared between domestic producers and the producers of exports. We also associate productivity losses with preferential trade agreements if an agreement's strict rules of origin induce the substitution of less efficient domestic inputs for more efficient imports from partners.

Each sector-specific bilateral trade flow may be covered by multiple FTAs. In such cases, the protection level applied to the flow is the lowest available among applicable agreements.

The utilization rate of an agreement is modeled with reference to three aspects of agreements:

- Preference margin of tariffs (utilization depends positively on large margins)

- Restrictiveness of the rules of origin ${ }^{12}$ (utilization inversely with restrictiveness)

- Size of the agreement (utilization varies positively with agreement size)

9 Research using this model can be found at: www.asiapacifictrade.org.

10 The RCEP text has been available since November 2020 but the actual tariff demobilization details only became available in machine-readable form very recently. The model will be updated in future using the actual tariff agreements, but it is unlikely that the results will differ much from the parameters assumed in these simulations.

11 Data suggest that utilization rates are well below unity (Kawai and Wignaraja, 2011).

12 This approach is similar to one used by Findlay and Urata (2010). 
The utilization rate is restricted to the range $16 \%-80 \%$.

Reductions in nontariff barriers are calculated as a product of three factors: (i) scores of each agreement in various issue areas, ${ }^{13}$ (ii) policy coefficients that translate scores into reductions in different nontariff barriers, and (iii) maximum reduction rates for each type of nontariff barrier.

When preferential tariffs are imposed in the model, the model recognizes that firms may undertake additional costs to meet the rules of origin that allow them to take advantage of preferential tariffs. These costs include the administrative burden of meeting rules-of-origin certification and possible additional costs in buying relatively expensive regional inputs to satisfy rules-of-origin tests. We represent these costs by adding iceberg costs to bilateral trade flows within an FTA. The size of the productivity penalty varies with the:

- Preference margin of tariffs (excess input costs rise with large margins)

- Restrictiveness of the rules of origin (excess input costs rise with restrictiveness)

- Size of the agreement (excess input costs decline with agreement size)

\section{Production and Trade}

Agriculture, mining and government services sectors are assumed to exhibit perfect competition. In these sectors a representative firm operates under constant returns to scale technology and trade is modeled using the Armington assumption for import demand. Manufacturing and private services are characterized by monopolistic competition and their structures of production and trade follow Melitz (2003). Sectors with monopolistic competition consist of continuum of firms that are differentiated by the varieties they produce and their productivity. Firms face fixed production costs, resulting in increasing returns to scale. There are also fixed costs and variable costs associated with exporting activities.

On the demand side, agents have Dixit-Stiglitz preference over the continuum of varieties. Since each firm is a monopolist for the variety it produces, it sets the price of its product at a constant markup over marginal cost. A firm enters domestic or export markets if the net profit generated from such sales is sufficient to cover fixed cost. This zero-profit condition defines the productivity thresholds for firm's entering domestic and exports markets, and in turn determines the equilibrium distribution of non-exporting firms and exporting firms and their average productivities. Fixed export costs and variable (iceberg) export costs are set to ensure that the productivity threshold for exporting is higher than the production threshold for domestic sales, so that only a fraction of firms with high productivity export. These firms supply both domestic and export markets. In contrast to some other applications of the Melitz model, the number of firms in each monopolistic sector is assumed to be fixed at any given time, though its sales in various markets vary.

There are five types of factors of production: capital, skilled and unskilled labor, agricultural land, and some other industry-specific natural resources. Except for natural resources, the factors are fully mobile across sectors. Production is modeled with multilevel production functions. At the top level, output is produced as a fixed combination of aggregate intermediate demand and value added. At the second level, aggregate intermediate demand is split into commodities according to Leontief technology. Value added is produced by a constant-elasticity-of-substitution (CES) capital-land bundle and aggregate labor. Finally, at the third level, aggregate labor is decomposed using a CES

13 Based list of issues was constructed based on various issues reported in the CPTPP and RCEP agreements. 
function into unskilled and skill labor, and the capital-land bundle is decomposed into capital and land (for the agriculture sector) or natural resources (for the mining sector).

\section{Factor Markets}

Capital is exogenously specified in any given year, based on the accumulation of capital through investments in previous years. After an initial year with a fixed incoming capital endowment, the model determines future capital endowments by adding current capital investment to the existing capital stock less depreciation.

This study is our first application of the model with endogenous labor supply. Labor demand $(L)$ for skilled and unskilled labor in each region is generated through the production mechanism above. Supplies of skilled and unskilled labor, in turn, depend on baseline projections of normal labor supply, adjusted depending on the ratio of real wages to baseline real wages:

$$
(A 1) S=S_{0}\left(w / w_{0}\right)^{\epsilon}
$$

where $S$ is the labor supply for skilled or unskilled labor in a given region, $S_{0}$ is the corresponding baseline labor supply, $w$ and $w_{o}$ are corresponding real wages, respectively, and $\epsilon$ is the corresponding uncompensated elasticity of labor supply with respect to real wages.

The elasticities used in the model result from a meta-analysis of time- and economy-specific estimates. The values were not derived by aggregating the underlying data, but rather by judgmentally "rounding" parameters to smooth variations across economies, types of labor, variable definitions, and estimation methods. Economy classifications are obtained from Serajuddin and Hamadeh (2020).

Table A1. Labor Supply Elasticities $\epsilon$

\begin{tabular}{lccc}
\hline Economy Income Class & 2020 Per Capita Income & Skilled Workers & Unskilled Workers \\
\hline High Income & $>\$ 12,535$ & 0.15 & 0.35 \\
Upper Middle Income & $\$ 4,046-\$ 12,535$ & 0.40 & 0.80 \\
Lower Middle Income & $\$ 1,036-\$ 4,045$ & 0.80 & 1.00 \\
Low Income & $<\$ 1,036$ & 1.20 & 1.50 \\
\hline
\end{tabular}

Source: Meta-analysis as explained in the text.

The judgmental parameters are based on estimates from many sources, including studies at the US Congressional Budget Office by McClelland and Mok (2012) and by McClelland, Mok, and Pierce (2014), academic papers including Evers, De Moou, and Van Vuuren (2008).

Other factor supplies are exogenously specified. Factor markets are closed by setting demand determined by the production system equal to supply (whether exogenously or endogenously set); these equations implicitly determine market clearing factor prices. 


\section{REFERENCES}

Association of Southeast Asian Nations (ASEAN). 1992. "Agreement on the Common Effective Preferential Tariff for the ASEAN Free-Trade Area.” Singapore, 28 January. https://asean.org/?static_ post=agreement-on-the-common-effective-preferential-tariff-cept-scheme-for-the-asean-freetrade-area-singapore-28-january-1992.

. 2003. "Declaration of Bali Concord II, 9th ASEAN Summit." https://asean.org/?static_post= declaration-of-asean-concord-ii-bali-concord-ii.

Australian Government, Department of Foreign Affairs and Trade. "Regional Comprehensive Economic Partnership." https://dfat.gov.au/trade/agreements/negotiations/rcep/Pages/regional-comprehensiveeconomic-partnership.aspx.

Baker McKenzie. 2020. “Understanding the Regional Comprehensive Economic Partnership Agreement (RCEP).” https://www.bakermckenzie.com/-/media/files/insight/publications/2020/12/ bakermckenzie_understandingrcep_dec2020.pdf?la=en.

Evers, Michiel, Ruud De Moou, and Daniel Van Vuuren. 2008. "The Wage Elasticity of Labor Supply: A Synthesis of Empirical Estimates.” De Economist 156: 25-43.

Ferrantino, Michael Joseph, Maryla Maliszewska, and Svitlana Taran. 2020. "Actual and Potential Trade Agreements in the Asia-Pacific.” World Bank Policy Research Working Paper 9496.

Findlay, Cristopher, and Shujiiro Urata, eds. 2010. Free Trade Agreements in the Asia Pacific. New Jersey: World Scientific.

Kawai, Masahiro, and Ganeshan Wignaraja. 2011. Asia's Free Trade Agreements: How is Business Responding? Cheltenham: Edward Elgar.

Krugman, Paul R. 1993. "What Do Undergrads Need to Know about Trade?" American Economic Review 83 (2): $23-26$.

McClelland, Robert, and Shannon Mok. 2012. "A Review of Recent Research on Labor Supply Elasticities.” Congressional Budget Office (CBO) Working Paper 12.

McClelland, Robert, Shannon Mok, and Kevin Pierce. 2014. "Labor Force Participation Elasticities of Women and Secondary Earners within Married Couples.” CBO Working Paper 6.

Melitz, Mark J. 2003. "The Impact of Trade on Inter-Industry Reallocations and Aggregate Industry Productivity." Econometrica 71 (6): 1695-1725.

Van der Mensbrugghe, Dominique. 2011. LINKAGE Technical Reference Document. Version 7.1. Washington: World Bank.

Monetary Authority of Singapore. 2021. Macroeconomic Review 20 (1): 25-34. 
Petri, Peter A., and Michael G. Plummer. 2016. "The Economic Effects of the Trans-Pacific Partnership: New Estimates.” Peterson Institute for International Economics Working Paper 16-2.

_ 2019. “China Should Join the New Trans-Pacific Partnership.” Peterson Institute for International Economics Policy Brief 19-1.

2020. "East Asia Decouples from the United States: Trade War, Covid-19, and East Asia's New Trade Blocs.” Peterson Institute for International Economics Working Paper 20-9.

Petri, Peter A., Michael G. Plummer, and Fan Zhai. 2012. The Trans-Pacific Partnership and Asia-Pacific Integration: A Quantitative Assessment. Policy Analyses in International Economics 98. Washington, DC: Peterson Institute for International Economics.

Pomfret, Richard. 2021. “Regionalism and the Global Trading System.” World Economy. 44 (9): 2496-2514.

Serajuddin, Umar, and Nada Hamadeh. 2020. "New World Bank Country Classifications by Income Level: 2020-2021.” World Bank Data Blog. https://blogs.worldbank.org/opendata/new-world-bankcountry-classifications-income-level-2020-2021.

Zhai, F. 2008. "Armington Meets Melitz: Introducing Firm Heterogeneity in a Global CGE Model of Trade.” Journal of Economic Integration 23 (3): 575-604. 


\section{Economic Implications of the Regional Comprehensive Economic Partnership for Asia and the Pacific}

The Regional Comprehensive Economic Partnership (RCEP) presents strong potential to mold regional trade and investment patterns well into the future and to influence the direction of global economic cooperation at a challenging time. This paper evaluates the RCEP's impact on global and regional incomes, trade, economic structure, factor returns, and employment using a computable general equilibrium model. The results suggest that the RCEP agreement could generate sizable global income gains. Together with the Comprehensive and Progressive Agreement on Trans-Pacific Partnership, RCEP will also strengthen the region's manufacturing supply chains, raising productivity and increasing wages and employment.

\section{About the Asian Development Bank}

ADB is committed to achieving a prosperous, inclusive, resilient, and sustainable Asia and the Pacific, while sustaining its efforts to eradicate extreme poverty. Established in 1966, it is owned by 68 members -49 from the region. Its main instruments for helping its developing member countries are policy dialogue, loans, equity investments, guarantees, grants, and technical assistance. 